\title{
AID, OWNERSHIP AND DEVELOPMENT
}

\section{THE INVERSE SOVEREIGNTY EFFECT IN THE PACIFIC ISLANDS}

John Overton, Warwick E. Murray,

Gerard Prinsen, Avataeao Junior Ulu and Nicola Wrighton

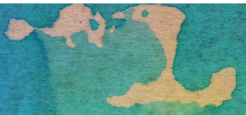




\section{Aid, Ownership and Development}

One of the key principles for effective aid programmes is that recipient agencies exert high degrees of ownership over the agendas, resources, systems and outcomes of aid activities. Sovereign recipient states should lead the process of development. Yet despite this well-recognised principle, the realities of aid delivery mean that ownership is often compromised in practice.

Aid, Ownership and Development examines this 'inverse sovereignty' hypothesis with regard to the states and territories of the Pacific Island region. It provides an initial overview of different aid 'regimes' over time, maps aid flows in the region, and analyses the concept of sovereignty. Drawing on a rich range of primary research by the authors and contributors, it focuses on the agencies and individuals within the Pacific Islands who administer and apply aid projects and programmes. There is indeed evidence for the inverse sovereignty effect; particularly when island states and their small and stretched bureaucracies have to deal with complex and burdensome donor reporting requirements, management systems, consultative meetings and differing strategic priorities. This book outlines important ways in which Pacific agencies have proved adept not only at meeting these requirements, but also asserting their own priorities and ways of operating. It concludes that global agreements, such as the Paris Declaration on Aid Effectiveness in 2005 and the recently launched Sustainable Development Goals, can be effective means for Pacific agencies to both hold donors to account and also to recognise and exercise their own sovereignty.

John Overton is a geographer who has worked on development issues and the Pacific region for over thirty years. His Pacific education began with a position at the University of the South Pacific in the mid-1980s and has continued through working with many students and colleagues from the Pacific Island region. He is currently Professor of Development Studies at Victoria University of Wellington, New Zealand.

Warwick E. Murray gained a $\mathrm{PhD}$ in geography at the University of Birmingham, UK and served as a lecturer in geography at the University of 
the South Pacific (1997-2000). Taking up a university role in Wellington in 2001 he has focused his research on development geographies of the Pacific Island region and Rim (including Latin America). An Editor of Asia Pacific Viewpoint since 2002, he is currently Professor of Human Geography at Victoria University of Wellington.

Gerard Prinsen teaches Development Studies at Massey University New Zealand, after a professional career in development practice. Most of his research revolves around local health and education services as spaces where small, rural, or remote communities negotiate their relationships with big metropolitan powers.

Avataeao Junior Ulu is an international development practitioner and has worked in the wider Pacific region since 2002. His master's degree focused on aid sovereignty in Samoa, and excerpts from his thesis can be found in this book. Junior is currently completing his $\mathrm{PhD}$ on migration, education and development with reference to Samoa. He also does development consultancy work in his spare time.

Nicola (Nicki) Wrighton spent many years working in the Pacific Island region for aid agencies, as a consultant and for Pacific organisations, including the Government of Tuvalu. Her master's degree in 2010 on aid and Tuvalu helped shape the Marsden Fund grant that funded the research for this book. She was working on her PhD on aid and sovereignty in the Pacific at Victoria University of Wellington when illness struck and she died tragically in 2014. 


\section{Aid, Ownership and Development}

The Inverse Sovereignty Effect in the Pacific Islands

\section{John Overton, Warwick E. Murray, Gerard Prinsen, Avataeao Junior Ulu and Nicola (Nicki) Wrighton}


First published 2019

by Routledge

2 Park Square, Milton Park, Abingdon, Oxon OX14 4RN

and by Routledge

711 Third Avenue, New York, NY 10017

Routledge is an imprint of the Taylor \& Francis Group, an informa business

(c) 2019 John Overton, Warwick E. Murray, Gerard Prinsen, Avataeao

Junior Ulu and Nicola Wrighton

The right of John Overton, Warwick E. Murray, Gerard Prinsen, Avataeao Junior Ulu and Nicola Wrighton to be identified as authors of this work has been asserted by them in accordance with sections 77 and 78 of the Copyright, Designs and Patents Act 1988.

All rights reserved. No part of this book may be reprinted or reproduced or utilised in any form or by any electronic, mechanical, or other means, now known or hereafter invented, including photocopying and recording, or in any information storage or retrieval system, without permission in writing from the publishers.

Trademark notice: Product or corporate names may be trademarks or registered trademarks, and are used only for identification and explanation without intent to infringe.

British Library Cataloguing-in-Publication Data A catalogue record for this book is available from the British Library

Library of Congress Cataloging-in-Publication Data

A catalog record for this book has been requested

ISBN: 978-0-367-00052-3 (hbk)

ISBN: 978-0-429-44481-4 (ebk)

Typeset in Sabon

by Apex Covantage, LLC

Visit the eResources: www.routledge.com/9780367000523 
IN MEMORY OF NICKI WRIGHTON 
$\because$ Taylor \& Francis

Taylor \& Francis Group

http://taylorandfrancis.com 


\section{Contents}

List of figures $\quad$ ix

List of tables xi

List of research insight boxes xii

List of authors and contributors xiv

List of abbreviations xvii

Acknowledgements $\quad \mathrm{xx}$

1 Aid in the Pacific in historic and geographic context 1

Aid in the Pacific Islands 1

Aid, ownership and sovereignty 7

The inverse sovereignty hypothesis 8

A brief history of colonisation and sovereignty in the Pacific 12 Researching aid in the Pacific 23

2 Global aid regimes and the Pacific

Introduction 29

Aid regimes: Pacific currents, global tides 29

Colonial transfers and the foundations of 'aid' in the Pacific 33

Modernisation and the development project 36

Neoliberalism 40

Neostructuralism 44

Retroliberalism 58

Summary and perspective 71

3 Aid in the Pacific Islands: an overview

Introduction: what is aid? 77

Mapping aid flows in the Pacific 80

Estimating non-DAC aid flows 120

Other forms of 'aid' 125

Conclusions: aid and the framing of the Pacific Islands 146 
viii Contents

4 Sovereignty

Introduction 151

The contemporary concept of sovereignty 152

Questioning Westphalian sovereignty 157

Oceanic sovereignty 160

An emerging 'Islandian' sovereignty? 174

Conclusions 179

5 The inverse sovereignty effect

Introduction 185

Compliance: the new conditionalities 186

The burden of consultation 201

The proliferation and complexity of aid institutions 208

The issue of capacity 216

Looking forward: inverse sovereignty and retroliberalism 232

Conclusion 233

6 Asserting Pacific sovereignty

Introduction 235

National sovereignty: engaging with the global aid environment 237

Paris in practice: recipient and donor relationships 244

Institutional sovereignty: developing national structures, policies and capabilities 246

State sovereignty and civil society 258

The everyday exercise of sovereignty: cafés and kava 263

Conclusions 280

7 Conclusions - aid and Oceanic sovereignty

Introduction 283

Pacific currents, global tides - new aid regimes 286

Oceanic sovereignty 293

References

295

Index 


\section{Figures}

1.1 The Pacific Islands 4

3.1 Total ODA to Pacific Island recipients 1965-2015 80

3.2 ODA to Pacific Island recipients by recipient 1965-2015 81

3.3 ODA to twelve core Pacific Island recipients 1965-2015 82

3.4 ODA to Pacific Island recipients by donor 1965-2015 84

3.5 Sectoral allocation of Australian ODA to Pacific Island recipients 1975-2014 89

3.6 Sectoral ODA allocations to Oceania 2002-2014 90

3.7 ODA to Pacific Island recipients 2010-2014 92

3.8 The Australian sphere 2010-2014 93

$\begin{array}{lll}3.9 & \text { The USA sphere 2010-2014 } & 94\end{array}$

3.10 The French sphere 2010-2014 95

3.11 The New Zealand sphere 2010-2014 96

3.12 Aid profiles 101

(a) Cook Islands 101

(b) Fiji 101

(c) Federated States of Micronesia 102

(d) Kiribati 102

(e) Republic of the Marshall Islands 103

(f) Nauru 103

(g) Niue 104

(h) Northern Mariana Islands 104

(i) Palau 105

(j) Papua New Guinea 105

(k) Samoa 106

(1) Solomon Islands 106

(m) Tokelau 107

(n) Tonga 107

(o) Tuvalu 108

(p) Vanuatu 108

(q) Wallis and Futuna 109

(r) French Polynesia 109 
$\mathrm{x}$ Figures

(s) New Caledonia 110

(t) Oceania Regional 110

3.13 Total aid per capita in the Pacific, 2010-2014 114

3.14 Grant assistance and concessionary loans from China and development banks 2010-2014 119

3.15 Remittances, ODA and exports in selected Pacific Island countries, 2014 


\section{Tables}

1.1 Countries and territories of the Pacific Islands 3

1.2 Colonisation of the Pacific Islands 16

2.1 Aid regimes 1950 to the present 31

2.2 The retroliberal aid regime and selected donors 61

2.3 Aid regimes in the Pacific - selected events, principles, goals and policies

3.1 ODA from all donors to Oceania 2010-2014 83

3.2 ODA and ODA per capita by recipient 113

3.3 China and selected major donors to Oceania 2010-2014 118

3.4 Estimated aid by donor to the Pacific, $2014 \quad 126$

3.5 Migration options and estimates of the proportional role of remittances

3.6 Summary of trade agreements and bodies relevant for the Pacific

5.1 Donor agencies in Oceania 2005-2014 209

6.1 ODA Disbursements to civil society in Oceania 2004-2015 262 


\section{Research insight boxes}

1.1 Arrivals in Tuvalu 5

1.2 Tino rangatiratanga and Maori sovereignty 10

2.1 New Zealand and the 'Realm' states 35

2.2 The MIRAB model 39

2.3 MDGs in the Pacific $\quad 47$

2.4 Aid modalities $\quad 50$

2.5 Australia: one clear objective? 54

2.6 RAMSI and rebuilding the state in Solomon Islands 57

2.7 Japan: JICA and new JICA 63

2.8 Supply-led aid: New Zealand's strategic plan 2015-2019 66

3.1 The French territories: how non-official aid can be helpful if it is done the French way $\quad 97$

3.2 Tuvalu, sovereignty and the Republic of China 116

3.3 South-South cooperation: Cuban medical training
and the Pacific

3.4 COFA: Palau, the Republic of the Marshall Islands and the Federated States of Micronesia 129

3.5 Niue: 'sweet spot' of sovereignty? 133

3.6 Trade preferences: the Fiji garment industry 142

4.1 Westphalia in the Pacific: the Kingdom of Tonga 153

4.2 Sovereignty for Tokelau? 156

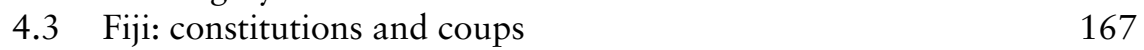

4.4 Pacific athletes and sovereignty: two tales 171

4.5 Flags of the Pacific 178

5.1 Vanuatu's Employment Law Reform and policy
conditionalities

5.2 The Pacific Islands Forum and indicators from Paris 193

5.3 A personal perspective on the Cairns Compact 198

5.4 Harmonising in practice: Tonga and energy policy 202

5.5 The Green Climate Fund and the 'harmonisation paradox' 203

5.6 Civil society and aid effectiveness in Tonga 211

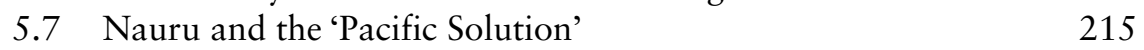

5.8 Sovereignty and size: observing a regional meeting 217 
5.9 Pacific regionalism and issues of capacity

5.10 An invitation for dialogue: locally engaged staff career pathways in Oceania

5.11 Media development to influence behavioural change: a case study in Solomon Islands

5.12 Chuuk and post-storm aid

5.13 Technical Advisors and capacity building in Tonga 230

6.1 Rapa Nui and Chile

6.2 Te Mato Vai: Cook Islands and the Tripartate project

6.3 Electric vehicles in Samoa?

6.4 Paris in Alofi: changing aid relationships between Niue and New Zealand

6.5 Tonga and the energy road map

6.6 Peseta Noumea Simi: a profile

6.7 Civil society and definitions of ownership

6.8 Language, law and sovereignty

6.9 A local lens for monitoring and evaluation in Vanuatu

6.10 Gagana and donors in Samoa

6.11 Hard and soft paradigms of project management

6.12 Respecting recipient status

7.1 The new project: the sustainable development goals and the Pacific 


\section{Authors and contributors}

\section{Authors}

John Overton is a geographer who has worked on development issues and the Pacific region for over thirty years. His Pacific education began with a position at the University of the South Pacific in the mid-1980s and has continued through working with many students and colleagues from the Pacific Island region. He is currently Professor of Development Studies at Victoria University of Wellington, New Zealand.

Warwick E. Murray gained a PhD in geography University of Birmingham, UK and served as a lecturer in geography at the University of the South Pacific (1997-2000). Taking up a university role in Wellington in 2001 he has focused his research on development geographies of the Pacific Island region and Rim (including Latin America). An Editor of Asia Pacific Viewpoint since 2002, he is currently Professor of Human Geography at Victoria University of Wellington

Gerard Prinsen teaches Development Studies at Massey University New Zealand, after a professional career in development practice. Most of his research revolves around local health and education services as spaces where small, rural, or remote communities negotiate their relationships with big metropolitan powers.

Avataeao Junior Ulu is an international development practitioner and has worked in the wider Pacific region since 2002. His master's degree focused on aid sovereignty in Samoa, and excerpts from his thesis can be found in this book. Junior is currently completing his $\mathrm{PhD}$ on migration, education and development with reference to Samoa. He also does development consultancy work in his spare time.

Nicola (Nicki) Wrighton spent many years working in the Pacific Island region for aid agencies, as a consultant and for Pacific organisations, including the Government of Tuvalu. Her master's degree was in 2010 on aid and Tuvalu helped shape the Marsden Fund grant that funded 
the research for this book. She was working on her PhD on aid and sovereignty in the Pacific at Victoria University of Wellington when illness struck, and she died tragically in 2014.

\section{Contributors}

Potoae Roberts Aiafi is currently Samoa Country Representative on the Pacific Leadership Programme and she teaches public policy at the National University of Samoa. She completed her PhD at Victoria University of Wellington in 2016.

Séverine Blaise specialises in international and development economics. She gained her PhD in economics in 2004 at Aix-Marseille University. She worked at the Australian National University before becoming senior lecturer at the University of New Caledonia in 2007.

Adele Broadbent completed her Master of Development Studies at Victoria University of Wellington in 2012 looking at media development in Solomon Islands. Adele worked for the Council for International Development in Wellington.

Karly Christ completed her Master of Development Studies at Victoria University of Wellington in 2012 which investigated the sovereignty movement in Rapa Nui with a particular emphasis on the role of women.

Peter C.L. Eafeare graduated with Bachelor of Education degree from the University of Papua New Guinea, a postgraduate Diploma in Library Studies, Victoria University of Wellington, and a diploma in Foreign Service, PNG Department of Foreign Affairs. He worked for twenty-nine years with PNG Foreign Affairs and is now a private consultant.

Finbar Kiddle graduated with a master's in Development Studies from Victoria University of Wellington in 2014 which focused on RAMSI in Solomon Islands.

Hannah Mackintosh completed her master's degree in Development Studies at Victoria University of Wellington in 2011. Her thesis considered how the universal concept of human rights is being engaged with and interpreted by Māori communities in Aotearoa New Zealand.

Alexander Mawyer is a cultural and linguistic anthropologist whose work has focused on the Mangarevan community in French Polynesia's Gambier Islands for over two decades. Associate Professor of Pacific Studies at the University of Hawai'i at Mānoa, he is currently editor of The Contemporary Pacific: A Journal of Island Affairs.

Julien Migozzi is a $\mathrm{PhD}$ candidate in urban and economic geography at the University of Grenoble Alpes, and currently a Research and Teaching 
Assistant at the École Normale Supérieure (Paris). With fieldwork based at Victoria University of Wellington, his master's focused on aid and urban development in New Caledonia (awarded by the École Normale Supérieure de Lyon).

Helen Mountfort completed a Master of Development Studies at Victoria University of Wellington in 2012 and her thesis focused on aid sovereignty in Tonga. She is currently a Programme Manager in the Risk and Resilience team at the Overseas Development Institute, UK.

Mattie Geary Nichol completed her master's degree in Development Studies at Victoria University of Wellington in 2014. Her thesis looked at monitoring and evaluation in government departments and non-governmental organisations in Vanuatu. Mattie is currently the international programmes coordinator for Family Planning New Zealand.

Pedram Pirnia gained a PhD in Development Studies from Victoria University of Wellington in 2016. He is the Officer responsible for promoting the SDSGs for the UN Association of New Zealand. He has travelled extensively in the Pacific region and currently lectures at Auckland University of Technology.

Sisikula Sisifa completed her PhD in Management at the University of Auckland Business School in 2016 and studied the project management practices used in development projects in Tonga. She is currently working as a Post-Doctoral research fellow at the University of Auckland Business School.

Felicia Pihigia Talagi completed her master's degree in Development Studies at Victoria University of Wellington in 2017 and studied aid relationships in Niue. She is currently working for the Government of Niue.

Faka'iloatonga Taumoefolau is an Australia National University graduate with a master's degree in International Affairs and with experience of working for government agencies in Tonga. He is currently pursuing his $\mathrm{PhD}$ in Development Studies at Victoria University of Wellington.

Klaus Thoma completed his master's degree in Development Studies at Victoria University of Wellington in 2014. He is currently establishing an NGO with the main interest of making electro-mobility accessible to small island nations which formed the topic of his action-research based thesis based on Samoa. 


\section{Abbreviations}

$\begin{array}{ll}\text { AAA } & \text { Accra Agenda for Action } \\ \text { ABC } & \text { Australian Broadcasting Corporation } \\ \text { ACP } & \text { African, Caribbean and Pacific countries } \\ \text { ADB } & \text { Asian Development Bank } \\ \text { AMD } & \text { Aid Management Division (Tonga) } \\ \text { ASEAN } & \text { Association of South East Asian Nations } \\ \text { AusAID } & \text { Australian Agency for International Development } \\ \text { AVID } & \text { Australian Volunteers for International Development } \\ \text { CDC } & \text { Cabinet Development Committee (Samoa) } \\ \text { CIDA } & \text { Canadian International Development Agency (disestablished) } \\ \text { CNMI } & \text { The Commonwealth of the Northern Mariana Islands } \\ \text { COFA } & \text { Compacts of Free Association (between the USA and Palau, } \\ & \text { the RMI and the FSM) } \\ \text { COP } & \text { Conference of the Parties (to the UN) } \\ \text { CSO } & \text { Civil Society Organisation } \\ \text { CSR } & \text { Colonial Sugar Refining Company } \\ \text { DAC } & \text { Development Assistance Committee (of the OECD) } \\ \text { DFAT } & \text { Department of Foreign Affairs and Trade (Australia) } \\ \text { DFID } & \text { Department For International Development (UK) } \\ \text { DWCP } & \text { Decent Work Country Programme } \\ \text { ECHR } & \text { European Court of Human Rights } \\ \text { EEC } & \text { European Economic Community } \\ \text { EIB } & \text { European Investment Bank } \\ \text { ELR } & \text { Employment Law Reform (Vanuatu) } \\ \text { EPAs } & \text { Economic Partnership Agreements } \\ \text { EU } & \text { European Union } \\ \text { EVs } & \text { Electric Vehicles } \\ \text { FAO } & \text { Food and Agriculture Organisation (of the UN) } \\ \text { FAP } & \text { Forward Aid Programme (Niue) } \\ \text { FATDC } & \text { Foreign Affairs, Trade and Development Canada } \\ \text { FDI } & \text { Foreign Direct Investment } \\ \text { FMS } & \text { Financial Management Systems } \\ \text { FSC } & \text { Fiji Sugar Corporation }\end{array}$




$\begin{array}{ll}\text { FSM } & \text { Federated States of Micronesia } \\ \text { GBS } & \text { General Budget Support } \\ \text { GDP } & \text { Gross Domestic Product } \\ \text { GFC } & \text { Global Financial Crisis } \\ \text { GFC } & \text { Green Climate Fund } \\ \text { GNI } & \text { Gross National Income } \\ \text { HIPC } & \text { Heavily Indebted Poor Countries } \\ \text { IEOM } & \text { Institut d'emission de l'Outre-Mer } \\ \text { IFAD } & \text { International Fund for Agricultural Development } \\ \text { IFC } & \text { International Finance Corporation } \\ \text { ILO } & \text { International Labour Organisation } \\ \text { IMF } & \text { International Monetary Fund } \\ \text { IR } & \text { International Relations } \\ \text { ISEE } & \text { Institutdela statistiqueet desétudeséconomiques (New Caledonia) } \\ \text { JBIC } & \text { Japan Bank for International Cooperation } \\ \text { JCfD } & \text { Joint Committee for Development (Government of Niue/ } \\ & \text { Government of New Zealand) } \\ \text { JICA } & \text { Japan International Cooperation Agency } \\ \text { LES } & \text { Locally Engaged Staff } \\ \text { MDGs } & \text { Millennium Development Goals } \\ \text { MFAT } & \text { Ministry of Foreign Affairs and Trade (New Zealand) } \\ \text { MIGA } & \text { Multilateral Investment Guarantee Agency } \\ \text { MIRAB } & \text { Migration, Remittances, Aid and Bureaucracy } \\ \text { MoFNP } & \text { Ministry of Finance and National Planning Tonga } \\ \text { MSG } & \text { Melanesian Spearhead Group } \\ \text { MSGTA } & \text { Melanesian Spearhead Group Trade Agreement } \\ \text { NAFTA } & \text { North American Free Trade Agreement } \\ \text { NDA } & \text { National Designated Authority (Green Climate Fund) } \\ \text { NDS } & \text { National Development Strategy (Solomon Islands) } \\ \text { NECC } & \text { National Energy Coordinating Committee (of Samoa) } \\ \text { NEMS } & \text { National Environmental Management Strategies } \\ \text { NGO } & \text { Non-Governmental Organisation } \\ \text { NZAID } & \text { New Zealand Agency for International Development } \\ & \text { (reintegrated into MFAT) } \\ \text { OCTs } & \text { Overseas Countries and Territories (of the EU) } \\ \text { ODA } & \text { Official Development Assistance } \\ \text { OECD } & \text { Organisation for Economic Cooperation and Development } \\ \text { OIA } & \text { Office of Insular Affairs (USA) } \\ \text { PACC } & \text { Project and Aid Coordination Committee (Tonga) } \\ \text { PACER } & \text { Pacific Agreement on Closer Relations } \\ \text { PACTAM } & \text { Pacific Technical Assistance Mechanism } \\ \text { PEFA } & \text { Public Expenditure and Financial Accountability } \\ \text { PIFS } & \text { Pacific Islands Forum Secretariat } \\ \text { PNG } & \text { Papua New Guinea } \\ \text { PRC } & \text { People's Republic of China } \\ & \end{array}$


PROFIT People, Resources, Overseas para-diplomacy, Finance/taxation and Transportation

PRS Poverty Reduction Strategies

PRSP Poverty Reduction Strategy Paper

RAMSI Regional Assistance Mission to the Solomon Islands

RMI Republic of the Marshall Islands

RSE Recognised Seasonal Employer (New Zealand)

SAPs Structural Adjustment Programmes

SBS Sectoral Budget Support

SDGs Sustainable Development Goals

SDL Soqosoqo Duavata ni Lewenivanua (United Fiji Party)

SDP Strategic Development Plan (Fiji)

SDS Strategy for Development (Samoa)

SIDS Small Island Developing States

SIG Solomon Islands Government

SOLMAS Solomon Islands Media Assistance programme

SPARTECA South Pacific Regional Trade and Economic Cooperation Agreement

SPC Pacific Community (formerly South Pacific Commission)

SPREP South Pacific Regional Environmental Programme

SWAps Sector Wide Approaches

SWP Seasonal Worker Programme (Australia)

TA Technical Advisors

TERM Tonga Energy Road Map

TESP Tonga Education Support Programme

TSDF Tonga Strategic Development Framework

TVET Technical and Vocational Education and Training programme (Tonga)

UN United Nations

UNAIDS UN programme on HIV/AIDS

UNCRD UN Centre for Regional Development

UNDP UN Development Programme

UNEP UN Environmental Programme

UNESCO UN Educational, Scientific and Cultural Organisation

UNFCC UN Framework Convention on Climate Change

UNFPA UN Population Fund

UNGA UN General Assembly

UNHCR the Office of the UN High Commissioner for Refugees (also known as the UN Refugee Agency)

UNICEF UN International Children's Emergency Fund (known as the UN Children's Fund)

UNRISD UN Research Institute for International Development

UNTA UN Technical Assistance

US-GAO United States Government Accountability Office

VSA Volunteer Service Abroad (New Zealand)

WTO World Trade Organisation 


\section{Acknowledgements}

The authors wish to acknowledge and thank many people and institutions who contributed to the genesis and production of this book. The substantive research originated in a project in 2011-2014 on the inverse sovereignty effect supported by the Marsden Fund of the Royal Society of New Zealand. This was complemented by a grant from the Fonds Pacifique of the French Government which allowed us to build research collaborations with colleagues in New Caledonia.

We were greatly assisted also by the continuous support and encouragement of Luamanuvao Dame Winnie Laban, the Assistant Vice Chancellor (Pasikifa) of Victoria University of Wellington. Winnie helped us communicate with many stakeholders in the aid world of the Pacific, particularly diplomatic representatives based in Wellington. Professor Vijay Naidu of the University of the South Pacific was also a key resource and Associate Professor Sailau Suaalii-Sauni helped shape our early thinking notably through her co-supervision of Nicki Wrighton's PhD thesis.

Adele Broadbent, as well as a contributor of material to the book, provided sharp and accurate proof reading. We also particularly thank Helen Mountford and Alex Mawyer who provided suggestions and material for various chapters as well as their named research insights boxes. All contributors to the book's research insights boxes provided more than words on a page. Some as masters and $\mathrm{PhD}$ researchers were part of the research team's meetings and deliberations as our ideas evolved and contributed much of the richness of the book through their fine field research. Others we met during the course of our work and we would particularly acknowledge the work of a cohort of excellent Pacific doctoral scholars (Potoae Roberts Aiafi, Sisikula Sisifa and Faka'iloatonga Taumoefolau, as well as Junior Ulu).

Finally, this research would not have been possible without the active participation of scores of Pacific Island officials, NGO workers, politicians, diplomats and community leaders and members who shared their experiences and views on aid and sovereignty in Oceania. 
$\because$ Taylor \& Francis

Taylor \& Francis Group

http://taylorandfrancis.com 


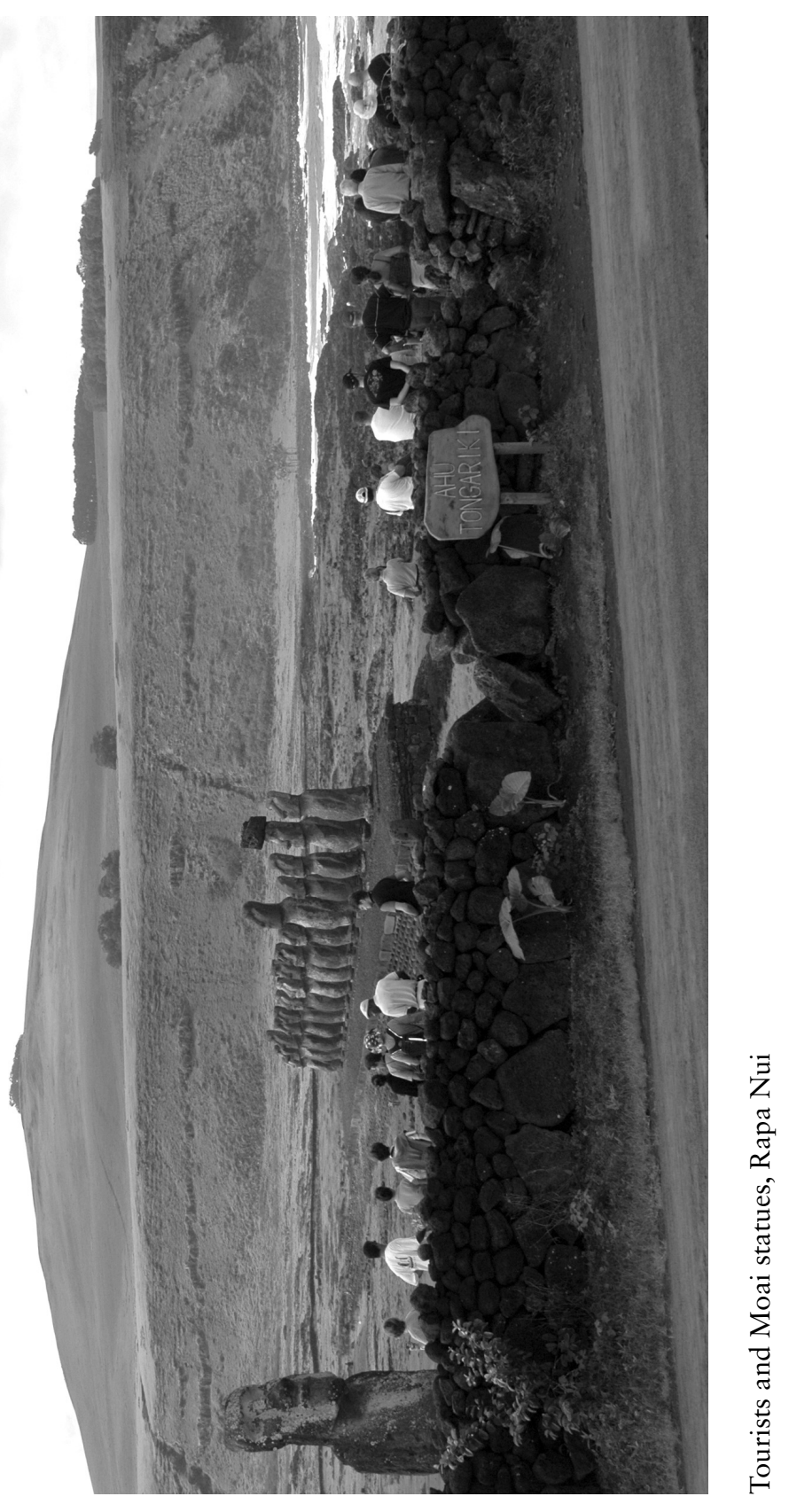




\section{Aid in the Pacific in historic and geographic context}

\section{Aid in the Pacific Islands}

There is considerable debate about the impact of aid in the Pacific. Critics of aid range from those who see it as a form of neo-colonial dominance to those who argue that it is at best ineffective and, at worst, a severe constraint on economic growth. The critics on the political left see aid as a tool of control over Pacific Island states by major donors (Stephen 2001). It is, thus, one of a number of instruments which diminish Pacific self-determination, belittle the ability of Pacific Island people to manage their own affairs, and frame the region and its residents as passive, in need, fragile and helpless. On the other hand, critics from the right of politics point to the very large volumes of aid flowing into the region and yet very poor economic performance: a situation that leads to the conclusion that 'aid has failed the Pacific' (Hughes 2003).

Yet despite these criticisms of aid in the region and the fact that many of its countries and territories have much more favourable development indices - in terms of literacy, income and life expectancy - than elsewhere in the Global South, aid levels have been maintained or increased in the past two decades. This has been the case even though the global financial crisis of 2007-2008 had severe impacts on the economies of the major donors to the region: USA, France, Australia, Japan and New Zealand. Furthermore, the aid landscape of the region has been continually transformed over recent years: China and other non-traditional donors have become more active; there have been fundamental shifts in the driving principles of established donors; and the climate change issue is becoming a more prominent feature of the narratives concerning aid and donor-recipient relationships.

The mainstream view of aid relationships, often expressed in documents by the OECD or UN, often builds on a set of stereotypes and truisms concerning the region and its 'inherent' geo-economic and geopolitical, and environmental vulnerability. This view encompasses the following assertions:

- The island states and territories ${ }^{1}$ of the Pacific comprise the most aiddependent region of the world. 


\section{Aid in the Pacific in historic and geographic context}

- Most of these entities are small in size, with populations numbering from thousands to less than one million; their land areas are fragmented in small islands generally over vast swathes of sea; and they occupy a marginal position in the global economy, hampered by very high unit transport costs and limited economies of scale.

- Colonial relationships persist with some territories remaining as integrated parts of metropolitan countries (Hawai'i, Rapa Nui) and others with partial degrees of self-determination (New Caledonia, Tokelau). Such relationships have particular implications for sovereign decisionmaking and aid volumes.

Whilst some of these assertions are empirical realities and do have detrimental implications for mainstream development indices, it is our contention that the broader outcomes of such factors are complex and contested. Although there are significant problems associated with political-economic power asymmetries, the Pacific is not necessarily as vulnerable or passive as orthodox analyses often portray.

The superficial view of aid relationships touched on above in the region disguises considerable difference and debate with regard to the way Pacific Island people experience, negotiate, manage and benefit from aid. It also hides significant questions about what aid is, why it is given and received and how it relates to processes of development. Experiences of aid in the region vary considerably. For example, although Papua New Guinea receives much more official aid than any other Pacific Island state - \$US 656 million in 2013 (see Table 1.1), its per capita aid receipts (\$US 89) are by far the lowest. On the other hand, the territory of Tokelau received only about \$US 24 million in 2013 but this amounted to over \$US 20,000 for each one of its 1200 residents.

The relationships that shape aid patterns are being played out through a complex set of agreements, and protocols as well as both institutional and personal networks. From the donor side, although the years 2000-2008 were marked by a strong promotion of poverty alleviation as the driving principle for aid, this did not displace the underlying self-interests of donors in engaging with the region. Various donors have recognised a long-standing obligation to some islands resulting from a colonial past; most have sought in some way to gain political support (as in the voting rights of Pacific states in international forums) through aid diplomacy; yet others have sought to use aid as a means of opening and building commercial relationships with the region to steer aid revenues back to their own economies through overt or subtle forms of what is described as 'tied aid'. For Pacific Island states, aid has become a critical and seemingly permanent element of their economies, paying for development projects (roads, airports, water supplies, agricultural schemes), supporting capacity building (training, education), and financing government expenditure (health, education). For many, aid has become, like remittances from citizens working overseas, a key determinant of local living standards. 
Table 1.1 Countries and territories of the Pacific Islands ${ }^{2}$

\begin{tabular}{|c|c|c|c|c|}
\hline & $\begin{array}{l}\text { Population } \\
\text { (estim 2013) }\end{array}$ & $\begin{array}{l}\text { Land area } \\
\left(\mathrm{km}^{2}\right)\end{array}$ & $\begin{array}{l}\text { Net ODA }{ }^{3} \\
\text { (2013 \$US mill) }\end{array}$ & $\begin{array}{l}\text { ODA per capita } \\
\text { (\$US) }\end{array}$ \\
\hline American Samoa & 56,500 & 199 & n.a. & n.a. \\
\hline Cook Islands & 15,200 & 237 & 15.29 & 1,006 \\
\hline $\begin{array}{l}\text { Federated States of } \\
\text { Micronesia }\end{array}$ & 103,000 & 701 & 143.16 & 1,390 \\
\hline Fiji & 859,200 & 18,333 & 91.24 & 106 \\
\hline French Polynesia & 261,400 & 3,521 & n.a. & n.a. \\
\hline Guam & 174,900 & 541 & n.a. & n.a. \\
\hline Hawai'i & $1,374,810$ & 16,634 & n.a. & n.a. \\
\hline Kiribati & 108,800 & 811 & 64.58 & 594 \\
\hline Marshall Islands & 54,200 & 18 & 93.91 & 1,733 \\
\hline Nauru & 10,500 & 21 & 28.78 & 2,741 \\
\hline New Caledonia & 259,000 & 18,576 & n.a. & n.a. \\
\hline New Zealand & $4,439,000$ & 268,107 & -457.31 & -103 \\
\hline Niue & 1,500 & 259 & 18.30 & 12,200 \\
\hline Norfolk Island & 1,895 & 35 & n.a. & n.a. \\
\hline $\begin{array}{l}\text { Northern Mariana } \\
\text { Islands }\end{array}$ & 55,700 & 457 & n.a. & n.a. \\
\hline Palau & 17,800 & 444 & 35.46 & 1,992 \\
\hline Papua New Guinea & $7,398,500$ & 462,840 & 656.54 & 89 \\
\hline Pitcairn & 45 & 47 & n.a. & n.a. \\
\hline Rapa Nui & 5,700 & 164 & n.a. & n.a. \\
\hline Samoa & 187,400 & 2,934 & 118.18 & 631 \\
\hline Solomon Islands & 610,800 & 28,000 & 288.32 & 472 \\
\hline Tokelau & 1,200 & 12 & 24.06 & 20,050 \\
\hline Tonga & 103,300 & 749 & 81.15 & 786 \\
\hline Tuvalu & 10,900 & 26 & 26.80 & 2,459 \\
\hline Vanuatu & 264,700 & 12,281 & 90.89 & 343 \\
\hline Wallis and Futuna & 12,200 & 142 & 105.53 & 8,650 \\
\hline
\end{tabular}

Source: South Pacific Commission, and OECD.Stat.

When examining aid in the Pacific then, it is clear that there are marked inequalities in power. Donors, in the form of governments negotiating bilateral arrangements, or international agencies representing many donors, appear to have much relative power. They can dictate the terms by which aid is received and spent and they can request or demand concessions, both economic and political. Donor power flows from the money they can offer but also from the way they can access or impose technical advice and expertise. Recipients, especially those from small countries, have small overstretched bureaucracies and the principle of being able to interact on an equal basis with donor countries is an illusion. Aid in the Pacific, despite all the rhetoric about partnerships, consultation and recipient ownership characteristic of global 'aidspeak', remains driven by donor systems, donor objectives and donor ways of operating.

The research on which this book is based began with this view above. Nicola Wrighton, our lead researcher, had spent many years working in 


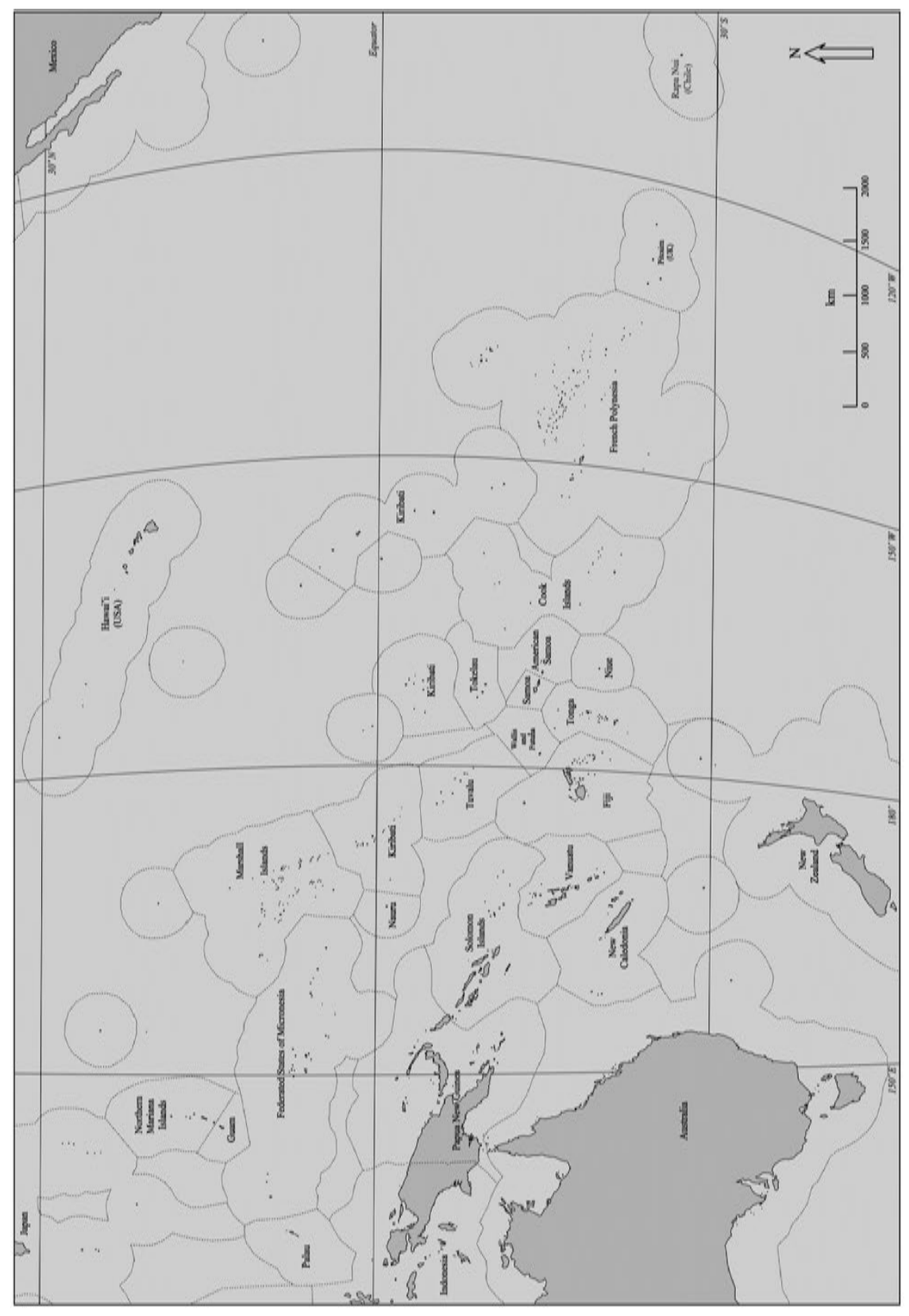

0
0
0
0
0
0
0
0
0
0
0
0
0
0
0
0
0 
the Pacific Islands, both for donor agencies (New Zealand) and, latterly, as an advisor for the Government of Tuvalu. In Tuvalu and Kiribati she was struck by the pressures faced by her local friends and colleagues (Wrighton 2010a, 2010b; Wrighton and Overton 2012). They had to receive an endless stream of diplomatic missions, journalists, academics and consultants, all visiting the islands to find information, consult, sign agreements, advise and 'do development'. They also had to represent their country at numerous meetings overseas, often necessitating them leaving their desks for weeks at a time. And amongst all this, they had to prepare reports (often to comply with donor requests for information) and, somehow, conduct their usual daily jobs, all within a context where they were expected to be readily accessible to local people. Box 1.1 illustrates the conclusions Wrighton drew from Tuvalu on the basis of her research there. Out of her work this project sought to examine the issue on a wider Pacific stage. Its central concern was the way officials and institutions in the Pacific could exert - or not - a degree of control over their own development given the resources and constraints that came with aid.

\section{Box 1.1 Arrivals in Tuvalu}

A survey of visitor arrivals took place over a three week period in 2008. Several tourists and a dozen or so unidentified visitors arrived during this period. However, at least thirty-four people entered the country as part of approximately twenty-five development-related missions or visits over the period. The list at the end of this box gives an idea of the development-related personnel who arrived in Tuvalu over the three week period.

As far as is known, apart from the Pacific Regional Infrastructure Facility mission, none of the other missions represented more than one donor or agency. This is a surprising result given that this is an environment where donors have committed to harmonisation through agreements such as the Paris Declaration on Aid Effectiveness and the Pacific Aid Effectiveness Principles.

This level of arrivals is consistent with annual visitor statistics in 2008 , collected by the Tuvalu government, which show that approximately 900 people entered Tuvalu on development-related business that year. This is approximately $10 \%$ of the total Tuvalu population (9729 at 1 July 2008 according to the Secretariat of the Pacific Community). Against the total population of Aotearoa New Zealand, this would roughly equate to 400,000 people coming into Wellington annually to discuss development-related matters. The equivalent in the UK would be approximately 6.5 million foreigners visiting government 
departments in London and in the USA a staggering 32 million foreigners knocking on government doors in Washington DC!

I undertook further 'back of the envelope' calculations. If each of the development personnel arriving in 2008 had meetings lasting an average of six hours with two Government officials in attendance (as a conservative estimate), five full-time staff would be needed to deal with well over 200 hours of meeting time per week.

Given the small size of Tuvalu's civil service, the probable squashing of a large proportion of these meetings into the short time period between the arrival of the Tuesday plane and the departure of the Thursday plane, and the general opinion expressed by officials that missions are becoming more frequent, this level of engagement must have a significant impact on the amount of time Tuvalu Government officials have to do their own jobs.

Identified development-related personnel that arrived over the three week period:

- the researcher

- an environmental filmmaker

- an environmental researcher

- several consultants related to the same ADB mission on restructuring State-Owned Enterprises

- two consultants relating to metrology (from different agencies on different missions)

- two consultants relating to tax (from different agencies on different missions)

- four consultants on the same labour and employment mission

- at least six people from four different missions from different agencies relating to the environment

- two Tuvalu Trust Fund Advisory Committee members

- an AusAID placement under Pacific Technical Assistance Mechanism (PACTAM)

- the PACTAM programme manager

- a consultant for the Pacific Regional Infrastructure Facility (PRIF) (jointly funded by AusAID, NZAID, ADB and World Bank)

- an ADB consultant working on the Integrated Framework for Trade

- a consultant working on the government accounts system

- an AusAID official

- a group of three people from the Australia Pacific Technical College

- a consultant with the Tuvalu Public Works Department

- a consultant working with Customs.

Source: Adapted from Wrighton (2010b: 9) 


\section{Aid, ownership and sovereignty}

Issues of aid are inextricably linked to questions of sovereignty. Although Pacific Island states and territories recognise the value of aid for their incomes and welfare, they are also strongly cognisant of the link between aid and dependence. Relying on donors, particularly on a single donor, for a large component of their economies means making compromises regarding power and control over their financial and other resources. Donors require a return on their 'investment' whether that be economic or political. The political or economic price of aid for Pacific Island governments is therefore a significant consideration to be kept in mind, even if it is not always made explicit by donors.

This concern about aid relationships between donors and recipients and the impact on sovereignty is not confined to the Pacific by any means. Indeed, we have identified it as a key element in determining how effective aid can be in addressing key development objectives in general (Murray and Overton 2011a). The global aid environment in the first decade of the present century was dominated by two key global agreements which underpinned the approach of most established donors, those who were members of the OECD's Development Assistance Committee (DAC). The first was the adoption of the Millennium Development Goals by the United Nations in 2000. These articulated eight key goals and associated targets with the aim of alleviating poverty on a global scale by 2015 . Subsequently, the MDGs began to guide many, if not most, development assistance. Aid programmes whether by multilateral agencies such as the World Bank or the UNDP or by major Western donor countries - adopted this 'poverty agenda' and during the following years, many committed more and more funding these MDGs. It meant that, with the alleviation of poverty as the key objective, regions such as the Pacific did receive more aid but the expanded aid programmes were now redirected to activities with an explicit poverty focus as defined by the MDGs: primary education, maternal and child health, gender equality in schools, etc.

The second key global agreement was the Paris Declaration on Aid Effectiveness of 2005. This was the second of ultimately four 'high level forums' on aid effectiveness brokered by the OECD. The Paris Declaration was the pivotal agreement and its five principles (ownership, alignment, harmonisation, managing for results, and mutual accountability) became central to development policy and practice worldwide. The principles were essentially concerned with improving the effectiveness of aid delivery yet, in retrospect, the core principles represented a remarkable degree of consensus about what made aid work. The ownership principle was the most important and, potentially, the most revolutionary. Despite thorny questions about ownership and legitimacy of different political entities, it acknowledged that the key lesson learnt from decades of aid delivery was that aid and development do not work when they are imposed on the supposed beneficiaries. Instead 
people, communities and states need to define their own development needs and prioritise resource allocation. They should develop their own strategies and solutions, they should be responsible for implementation and monitoring, and they need to live with, and be accountable for, the results.

Supported by the alignment and harmonisation principles, the Paris Declaration had the potential to rewrite global development aid practice. Reversing previous neoliberal approaches to limit and diminish the role of the state in development, it saw a lead role for recipient governments in developing poverty reduction strategic plans and overseeing long-term programmes through government budgets and institutions. And rather than replacing or replicating such state-led activities, donors agreed to support such state efforts, cofunding development efforts through Sector Wide Approaches (SWAps) or, ideally, General Budget Support (GBS). State institutions became critical and, in principle, donors were to step back and let local institutions take the lead.

As with the MDGs, the Paris Declaration had profound effects on the aid environment in the Pacific. Pacific governments were expected to articulate strategic three to five-year poverty reduction plans, all government departments were to implement and monitor these plans and a range of civil society organisations were to be consulted and be involved, along with government, in reducing poverty. In theory, the ownership principle would empower state institutions. Ideally, recipients would lead and donors follow: this would be a remarkable inversion of the apparent power imbalances noted above and national sovereignty, in making development policies, would be respected and encouraged.

However, the reality of aid turned out to be somewhat different. Understandably, donors were reluctant to merely pass on funding without robust systems for ensuring that funds were spent appropriately. They also wanted to ensure that governments consulted widely with their populations and were both transparent in the way their revenues were spent and accountable for any failures or misspending. Donors were keen to ensure that systems, plans and audits conformed to international standards and templates to make the global aid system consistent, workable and understandable. The result of these donor concerns was a plethora of systems, practices, policies, plans, agreements and consultations, all in the name of aid effectiveness but with the end result of a set of new conditionalities imposed upon recipients. Unlike the heavy policy conditionalities imposed during the neoliberal era of the 1980s and 1990s - most notably through much-criticised Structural Adjustment Programmes - these were 'process conditionalities'. They were to do with the way officials and governments operated - sets of practices that were required as the price of higher aid receipts.

\section{The inverse sovereignty hypothesis}

So whilst the Paris Declaration discussed above made much of 'ownership', raising the prospect of enhanced local sovereignty over development, the 
practice of aid threatened to challenge the independence and flexibility of Pacific governments. Supporting or restoring the recipient state's sovereignty was hailed as the overarching goal, but the actual exercise of sovereignty was curtailed and prescribed by donors. This we termed the 'inverse sovereignty effect': the Paris Declaration aimed to reinforce policy sovereignty, but it was undermining and reversing it in practice (Overton et al. 2012; Murray and Overton 2011b).

This inverse sovereignty hypothesis guided our research project in the Pacific. Here it was to be given particular form, shaped by the complex issues of scale and political statuses in the Pacific. Nicki Wrighton's observations in Tuvalu (2010b) were a starting point: do small states such as Tuvalu struggle with these new demands and conditionalities more than larger ones? How do local officials cope with these demands in practice? How relevant are aid agendas at the global level to the realities of small island states? Furthermore, these questions could be broadened and reconstituted elsewhere in the Pacific: do those states that are less politically independent face fewer or more demands from their donors, along with higher aid volumes? Are there examples of some Pacific states or regional Pacific institutions that are able to use these new principles better than others? How do Pacific Island officials perceive and work within the aid policy environment in different ways? We hoped that if the inverse sovereignty hypothesis was confirmed, then it would be possible to inform policy at national, regional and global levels so that ownership and sovereignty could be better respected and enhanced.

In pursuing this research, the issue of sovereignty became a central concern. We were influenced by two different sets of debates in the Pacific. One involved the contentious matter of political independence. The Pacific region had been colonised by Western states during the nineteenth and early twentieth centuries and decolonisation occurred rather later and more slowly than in many other parts of the world. Independence was sought and fought for in the region. In some cases, it came relatively smoothly, and full independence was granted to countries such as Papua New Guinea and Solomon Islands (see Table 1.2 below). Elsewhere, the move to independence seemed to stall. In Kanaky/New Caledonia some strong indigenous calls for independence in the 1980s were resisted by other residents. In smaller countries, such as Cook Islands, Niue or Palau, questions about viability of an independent state were tackled by adopting a partial model, where full internal selfgovernment was coupled with a voluntary 'free association' arrangement where the former colonial power retained some powers and responsibilities and citizens were able to retain some rights within the metropole. And in yet other places, such as Tokelau, moves to full independence from New Zealand have been debated, but not followed through. Other Pacific islands, such as Wallis and Futuna, have never really considered independence from France. Political sovereignty remains a contested and complex notion in the Pacific Islands region and the relationship between national sovereignty and development is one we return to in chapter 4. 
The second approach to sovereignty that informed this research came from two directions. Firstly, given that most of the research team lived and worked in Aotearoa/New Zealand, the debates there about Maori sovereignty - tino rangitiratanga - provided insights into a concept that is much more intricate and complex than the macro level and Eurocentric concept of state sovereignty (see Box 1.2). Instead issues of self-determination and control over one's own development at community or iwi (tribal) level arise and suggest that sovereignty should be seen as many-layered, multi-scalar and inherently complex. Secondly the work of Epeli Hau'ofa, in suggesting a Pacific world that extends beyond national borders and spans the ocean in networks of kin (Hau'ofa 1993), was very influential in highlighting the critical agency of Pacific Island peoples and kinship groups in identifying and exploiting a range of opportunities. For Hau'ofa, Pacific cultures and environments are not constraints, and adjectives such as 'small', 'traditional', 'communal' or 'maritime' are not limiting descriptors but help define a range of resources that Pacific people have proven adept at using.

\section{Box 1.2 Tino rangatiratanga and Maori sovereignty}

\section{Hannah Mackintosh}

"Indigenous scholars have argued that sovereignty emanates from the unique identity and culture of peoples and is therefore an inherent and inalienable right of people to the qualities customarily associated with nations" (Barker 1995: 3). From this perspective sovereignty is connected to identity and is defined within the context of particular local realities which are the result of specific historical experiences. This more holistic view moves sovereignty away from absolute power towards the ability to assert a common identity based on cultural practices, language and shared historical experiences.

The term 'sovereignty' itself is not often used within the Māori sovereignty movement. For many Māori, sovereignty is a European concept that carries the weight of a colonial history (Durie 1998; Moon 2000) and does not truly convey the meaning behind Māori aspirations and demands. For this reason, the more favourable term is tino rangatiratanga or self-determination ${ }^{4}$ (Melbourne 1995). Article Two of the Treaty of Waitangi of 1840 assured Māori they would retain their tino rangatiratanga over "lands, villages and all things precious" (Orange 2004). Sovereignty for Māori in Aotearoa, therefore, revolves around the assertion of tino rangatiratanga.

Māori calls for tino rangatiratanga in Aotearoa are often viewed as a Māori secessionist claim. Most Māori, however, view it as neither antagonistic nor threatening but rather it is a call for autonomy 
and control over all decision-making relating to or impacting Māori (Dixon 2006; Durie 1998; O'Sullivan 2006). It represents the freedom to be able to engage meaningfully in all aspects of society as Māori and to be respected as a partner in the Treaty of Waitangi. This is therefore not necessarily a direct threat to the sovereign power of the state. However, it does call for the rearrangement of the current social order, "It is about forging a new social contract for living together differently" (Maaka and Fleras 2005: 103).

Not all Māori agree on the meaning or the aims of tino rangatiratanga. In reality, it has different meanings for different individuals and collectives (Maaka and Fleras 2000). This has resulted in a movement which embraces a whole range of social, cultural, economic, spiritual and political aspirations (Chile 2006). Upon considering tino rangatiratanga, Mason Durie (1998: 239) sums up the overall aspirations of Māori as:

Economic self-sufficiency, social equity, cultural affirmation and political power, stand alongside a firm Māori identity strengthened by access to whānau, hapū and iwi and confirmation that future generations of Māori will be able to enjoy their lands and forests, rivers and lakes, harbours and the sea and the air.

Thus an appreciation of the debates concerning tino rangatiratanga can provide insights into wider understandings of sovereignty. Moving away from a simple state-centred view of absolute political power, we can appreciate that sovereignty can, and should, encompass how people and communities can exert ownership and control over their own resources, cultures and identity. Such forms of self-determination, then, have to do with politics and institutions but also with how sovereignty is practiced, negotiated and felt on an everyday basis over a range of systems, interactions and relationships.

Extracted and modified from: Mackintosh (2011)

Putting these ideas together, this research adopts a view of sovereignty that seeks to move beyond a simple notion of the supposed costs and benefits of political independence at national level - though that remains important and instead suggest an additional view of sovereignty that stresses its malleable, diverse and multi-layered nature. Within the context of international aid, sovereignty is practiced and performed on an everyday basis and is not just given and accepted as an absolute state of (political) being. We place particular emphasis on the role of key agents in the aid world: the officials and politicians from both sides, the consultants, researchers, journalists and 
NGO workers who are engaged in aid negotiations, communication, implementation and evaluations.

Despite the clear asymmetries, the crucial issue is how recipients negotiate and interact in overt and less explicit ways in order to challenge the power inequities and capability problems that undermine sovereignty. As a consequence, the costs and benefits of aid to all parties involved are manifested in complex ways across the region. Three major factors affect the interactions and negotiation. Firstly, size and scale are important. Larger states receiving aid may have more to offer by way of resources and have better capacity to deal with the requirements for compliance and implementation that come along with aid inflows. Smaller states may struggle to deal with the burden of aid administration - as we shall see - yet they can also use their size to advantage, often being able to attract more from donors in per capita benefits than their larger neighbours. Secondly, political status is also a key factor. There is a clear correlation between dependence and aid: sovereign independent states generally attract much less aid than those territories that maintain higher degrees of association with a metropolitan 'patron' with whom they have a colonial history. And finally, culture is critical. This is not a simple anthropological matter of shared language, rituals, understandings and history - though these factors are of influence - but a more general issue of political and bureaucratic practice in the ways Pacific Island officials deal in different ways, through their attitudes, behaviours and policies, with donor institutions and officials.

If ownership and - by extension - sovereignty are to promote the efficacy of aid and development, then we need to examine it not only as a set of complex political and technical agreements and arrangements but also as an even more intricate set of practices, attitudes, protocols and relationships that work through dynamic personal and institutional networks that have evolved over a long history. In order to contextualise our research we turn in the subsequent section to a brief examination of colonial and postcolonial Pacific history emphasising the diverse and dynamic nature of sovereignty across space and time.

\section{A brief history of colonisation and sovereignty in the Pacific}

The interaction of the Pacific Islands with outside powers has moulded its sovereignty over a long period of time. Colonialism and negotiating the influence of external powers over the sovereignty of local polities on Pacific islands did not begin with the establishment of the formal European empires of the 1800s, although this is when it was first codified in a Western legal and political sense. The Pacific was first settled up to 40,000 years ago by humans moving into what is now Papua New Guinea. These people also spread subsequently into the islands of Melanesia (Solomon Islands, Vanuatu, New Caledonia and Fiji). Later, more extensive settlement was carried out by Austronesian people with groups crossing through the Indonesian 
archipelago and Papua New Guinea into what is now Melanesia around 4000BP (Before Present), including Fiji by approximately 3000BP. The settlement of the broad area of Polynesia began around 2500BP with the last areas of the triangle to be settled being Hawai'i (1500 BP), Rapa Nui (1000BP) and Aotearoa (perhaps 800-1000BP) (Thorne and Raymond 1989). Conflicts over control of resources - at the time probably expressed through tributary obligation, but in today's terms associated with what we term sovereignty - were likely to have been many and, to an extent, drove the onward migrations of the Pacific peoples.

European contact was made first in the early 16th century with Dutch, Spanish and Portuguese explorers. It was in the 1700s and 1800s that European influence was consolidated through the actions of missionaries, traders and whalers that had built over previous centuries (Campbell 1989; Howe 1984, also Spate 1979). Competition between the two great maritime powers of the time, the British and the French, partly drove this. Firth (2000) refers to this early group of colonists as the 'buccaneers' of global capitalism. The South Pacific became an important strategic location given the political rivalries that existed during this phase of European expansion as it moved from the mercantile to the industrial phases of colonialism. The European powers brought with them their own particular concepts and philosophies such as, for example, Christianity, private property, money and moral codes regarding race, class and gender. Colonists and their supporters back in Europe considered these concepts as tools and as signifiers of progress and civilisation.

While there were economic as well as political interests that drove European colonisation of the Pacific - economic resources such as copra, fruit and sugar, and later minerals, served as inputs in the European industrial complex - resource extraction did not represent the main driver of colonisation in the Pacific. In fact, early colonisation throughout the Pacific in the first half of the 19 th century was a rather slow process, still largely driven by mercantile trading interests both of European and Pacific people. We would describe the early colonisation process as one of polycolonialism: a complex and geographically differentiated colonisation process of the Pacific region by different actors, for different motives, at different scales and driven by an exogenous as well as endogenous dynamics. ${ }^{5}$ The exogenous dynamic came from early European traders and missionaries who - in order to support their business and proselytisation activities - called upon the governments of their mother countries to follow them and establish 'law and order'. In other words, the early settlers asked for political and material support from their governments to secure their often tenuous footholds in the Pacific and regulate the conflicts between themselves, as well as with Pacific peoples.

Generally speaking, the European metropoles provided this support rather reluctantly and certainly not in the volumes asked for by the early settlers. If anything, European governments of the time embraced policies emanating from Adam Smith's classic liberalism - free trade and minimal state intervention - and sought the expansion of global trade by private 


\section{4}

Aid in the Pacific in historic and geographic context

trading houses. As such, the first dynamic of European colonisation in the Pacific was propelled by the establishment of trading posts of these trading houses, for which their shareholders alone bore the costs. One form of support European governments could give these trading houses was to strengthen their chief traders' positions by designating them their local diplomatic representatives. As representatives of their countries, these 'consuls' could then call upon their nations' battleships to settle business disputes with local adversaries or competing trading houses. For example, the trader John Brown Williams became the US representative in Fiji in 1846 and in 1849 he called in US warships to assert and expand his trade network against local chiefs. Similarly, the network of German trading house Godeffroy - having Chancellor Bismarck as a shareholder - represented Germany throughout the Pacific, with trading posts-cum-consulates in Samoa, Tuvalu and Tahiti. ${ }^{6}$

The endogenous dynamic that facilitated the formalisation of European colonisation resulted from the diverse set of formal treaties, business deals, and informal arrangements between local chiefs and political elites throughout the Pacific and - on the other hand - the European missionaries and traders-cum-consuls. These local Pacific elites used these relationships with European powers to increase their trade revenue and military capabilities and subsequently dominate or conquer neighbouring polities, or to engage in dynastic struggles for local power within Pacific polities. New Zealand's northern Māori polities, for example, were the first to acquire firearms through European traders and they began a violent and dramatic expansion of their influence throughout the entire North Island and as far as the Chatham Islands. These 'Musket Wars' took most of the first half of the 19th century and left tens of thousands of Maori dead or enslaved, overhauling the political map of Aotearoa/New Zealand. An example of a Pacific dynastic struggle that was exacerbated was the First Samoan Civil War between 1886 and 1894, characterised by increasingly violent warfare among rival local factions, each faction having successfully obtained support from equally rivalrous trading houses from Germany, the USA and Britain. This support started with the supply of guns and credit, but later expanded to military training and, after that, combat troops and even warships.

While the encounter between Pacific and European peoples and powers initially resulted in what we termed a polycolonial process, driven by endogenous and exogenous actors alike and each for their own motives, it generally ended by the late 19th century with a clear hegemony or full formal control over Pacific islands by European powers. Control or dominance over Pacific islands was ultimately determined in formal arrangements between European and American colonial powers. This process began notably with the Treaty of Waitangi between the majority of Māori chiefs and the British crown in New Zealand (1840) and, for France, with its unilateral declaration of New Caledonia as French territory in 1853. The process ended around 1900. A clear example of European and American control at the expense of Pacific political elites was the Tripartite Convention on Samoa of 1899 
in which Germany, Britain and the USA partitioned the islands of Samoa without any involvement of local parties. The three parties agreed to respect the territorial claims on Samoa by the USA and Germany and in exchange for withdrawing its claim on Samoan territories, Britain was offered the 'rights' to Tonga, from which Germany duly withdrew its claims and trading posts. Table 1.2 summarizes European colonialism and independence in the Pacific Islands. Although generally Europeans did not settle in vast numbers in the region, their influence was profound and far reaching, leading to the establishment of British, French and German colonies in the late 1800s and early 1900s. The German territories included Samoa (1900-1914) and German New Guinea (1884-1914). The French added French Polynesia and Wallis \& Futuna in the 1880s and the British presence was centred on Fiji (1874), Papua and Solomon Islands. Thus, until the conclusion of the First World War, the region was controlled by three European powers though their effective power in many territories, especially in Melanesia, was relatively thin. In the late 19th century the USA added a number of territories including American Samoa and Guam, and came to play an especially important role in Micronesia mainly gaining control where the Spanish were defeated or had sold their colonial possessions. European populations settled in the region, but only in New Zealand and Hawai'i were they able to usurp local polities and establish a degree of independence from the colonial power. French settlement in Polynesia and New Caledonia was relatively extensive but the territories remained part of metropolitan France in a formal sense.

In sum, in our view, colonialism in the Pacific throughout most of the 19th century did not involve a straightforward and successively wider military conquest of Pacific territory by European and American powers. Instead, in the Pacific the contacts with newly arrived non-Pacific actors created a process of polycolonialism; a complex dynamic of trade, conflict and competition among European and North American powers, within and between neighbouring Pacific polities, and also between Pacific peoples and the increasingly present outsiders. However, at the start of the 20th century, the overall balance of power and control was concentrated in the hands of the US and European governments as imperial control over Pacific islands was formalised in international diplomatic treaties. This launched the Pacific into mercantilist production circuits at the periphery of the evolving global economy.

The impacts are summarised by Firth writing on colonialism in 2000:

Globalisation when combined with colonial rule meant incorporation into the global economy on terms that suited the interests of the colonial powers ... the place of the tropical world in the first globalization was to be subordinate to the temperate and developed world.

Colonialism was unevenly felt across the region. In some places, such as Hawai'i and Rapa Nui, the indigenous authority was overthrown, land 
Table 1.2 Colonisation of the Pacific Islands

\begin{tabular}{|c|c|c|}
\hline Country & Comments on colonial history & $\begin{array}{l}\text { Present political } \\
\text { status }\end{array}$ \\
\hline $\begin{array}{l}\text { American } \\
\text { Samoa }\end{array}$ & $\begin{array}{l}\text { After rivalry between Great Britain and } \\
\text { Germany, the USA was granted the terri- } \\
\text { tory through the } 1899 \text { Tripartite Agree- } \\
\text { ment. Named American Samoa in } 1911\end{array}$ & $\begin{array}{l}\text { 'Unincorporated' US } \\
\text { territory (1967) }\end{array}$ \\
\hline Cook Islands & $\begin{array}{l}\text { European influence and Christianity spread } \\
\text { in } 1800 \text { s. British protectorate in } 1888 . \\
\text { Annexed by UK in } 1900 \text {, and incorporated } \\
\text { into the colony of New Zealand } 1901\end{array}$ & $\begin{array}{l}\text { Self-governing in } \\
\text { free association } \\
\text { with NZ (1965) }\end{array}$ \\
\hline $\begin{array}{l}\text { Federated } \\
\text { States of } \\
\text { Micronesia }\end{array}$ & $\begin{array}{l}\text { Annexed by Spain in } 1885 \text {, sold to Ger- } \\
\text { many in } 1899 \text { and captured by Japan in } \\
\text { WW1. US administration established } 1947 \\
\text { as part of the Trust Territory of the Pacific } \\
\text { Islands. Self-governing as FSM } 1979 .\end{array}$ & $\begin{array}{l}\text { Independent with } \\
\text { compact of free } \\
\text { association with } \\
\text { USA (signed 1986, } \\
\text { formalised 1990) }\end{array}$ \\
\hline Fiji & $\begin{array}{l}\text { European settlers in the } 1800 \text { s. Ratu Caka- } \\
\text { bau self-declared Tui Viti (king of Fiji) } \\
\text { offered to cede to the UK in order to } \\
\text { offset US and French power. Accepted by } \\
\text { UK } 1874\end{array}$ & Independent (1970) \\
\hline $\begin{array}{l}\text { French } \\
\text { Polynesia }\end{array}$ & $\begin{array}{l}\text { First European settlers } 1790 \text { s. } 1842-1888 \text { : } \\
\text { Island groups unilaterally declared French } \\
\text { protectorate }\end{array}$ & $\begin{array}{l}\text { ‘Overseas collec- } \\
\text { tivity’ of France } \\
\text { (2003) }\end{array}$ \\
\hline Guam & $\begin{array}{l}\text { Annexed by Spain } 1668 \text {, ceded to USA } \\
\text { 1898. Occupied by Japan 1941-1944, re- } \\
\text { occupied by USA }\end{array}$ & $\begin{array}{l}\text { 'Unincorporated' US } \\
\text { territory (1950) }\end{array}$ \\
\hline Hawai'i & $\begin{array}{l}\text { Kingdom of Hawai'i overthrown in } 1893 . \\
\text { Republic led by US interests declared. } \\
\text { Annexed to USA 1898, and fully incorpo- } \\
\text { rated following referendum in } 1959\end{array}$ & $\begin{array}{l}\text { Integrated within } \\
\text { USA (state - 1959) }\end{array}$ \\
\hline Kiribati & $\begin{array}{l}\text { British Protectorate of Gilbert and Ellice } \\
\text { Islands became UK colony in } 1916 . \text { Occu- } \\
\text { pied by Japanese during WW2 until } 1943 . \\
\text { Ellice Islands became Tuvalu in 1978, and } \\
\text { Gilbert Islands and other groups became } \\
\text { Republic of Kiribati in } 1979\end{array}$ & Independent (1979) \\
\hline $\begin{array}{l}\text { Marshall } \\
\text { Islands }\end{array}$ & $\begin{array}{l}\text { Annexed by Spain 1874, sold to Germany } \\
\text { 1884. Occupied by Japan in WW } 1 \text { and } \\
\text { administered by Japan as a trust territory } \\
\text { 1919-1944. US administration } 1947 \text { as } \\
\text { part of the Trust Territory of the Pacific } \\
\text { Islands. Self-governing } 1979\end{array}$ & $\begin{array}{l}\text { Independent with } \\
\text { compact of free } \\
\text { association with } \\
\text { USA (1986) }\end{array}$ \\
\hline Nauru & $\begin{array}{l}\text { Annexed by Germany } 1888 \text {, captured by } \\
\text { Australia } 1914 \text {, administered as a trust } \\
\text { territory by Australia, NZ \& UK 1919- } \\
\text { 1941. Occupied by Japan 1942-1945. } \\
\text { Australia, NZ \& UK trust territory } 1947\end{array}$ & Independent (1968). \\
\hline $\begin{array}{l}\text { New } \\
\text { Caledonia }\end{array}$ & $\begin{array}{l}\text { First European settlers, traders, missionaries } \\
\text { and blackbirders in the } 1840 \text { s. Unilaterally } \\
\text { declared a French possession in } 1853\end{array}$ & $\begin{array}{c}\text { 'Special Collectivity' } \\
\text { of France (1999) }\end{array}$ \\
\hline
\end{tabular}




\begin{tabular}{|c|c|c|}
\hline Country & Comments on colonial history & $\begin{array}{l}\text { Present political } \\
\text { status }\end{array}$ \\
\hline New Zealand & $\begin{array}{l}\text { Became British territory } 1840 \text { following the } \\
\text { Treaty of Waitangi. Self-governing } 1857 \text {, } \\
\text { dominion status } 1907 \text {, 'equal status' with } \\
\text { entities of the British Empire 1931, full } \\
\text { separation of the UK and NZ crown in } \\
1947 \text { when this was ratified. } 1986 \text { Con- } \\
\text { stitution Act adopted. } 1987 \text { revoked all } \\
\text { residual UK legislative power }\end{array}$ & $\begin{array}{l}\text { Independent (though } \\
\text { some technical } \\
\text { debate remains } \\
\text { concerning the } \\
\text { date of and exact } \\
\text { nature). } 1947 \text { full } \\
\text { sovereignty and } \\
1986 \text { Act led to } \\
\text { free-standing con- } \\
\text { stitutional monar- } \\
\text { chy in } 1987\end{array}$ \\
\hline Niue & $\begin{array}{l}\text { Acquired by UK as a protectorate in } 1900 \text {, } \\
\text { passed to NZ } 1901 \text { as part of Cook } \\
\text { Islands. Separate status as NZ colony } \\
1903\end{array}$ & $\begin{array}{l}\text { Self-governing in } \\
\text { free association } \\
\text { with NZ (1974) }\end{array}$ \\
\hline $\begin{array}{l}\text { Norfolk } \\
\text { Island }\end{array}$ & $\begin{array}{l}\text { Part of New South Wales colony - UK } \\
\text { (1788). Territory of Australia } 1913\end{array}$ & $\begin{array}{l}\text { External territory of } \\
\text { Australia (1979) }\end{array}$ \\
\hline Northern & Acquired by Spain c. 1668 , sold to Germany & US territory with \\
\hline Mariana & 1899. Japanese UN mandate 1919, US & ‘commonwealth’ \\
\hline Islands & $\begin{array}{l}\text { administration } 1947 \text { as part of the Trust } \\
\text { Territory of the Pacific Islands }\end{array}$ & status $(1978)$ \\
\hline Palau & $\begin{array}{l}\text { Acquired by Spain } 1574 \text {, sold to Germany } \\
1899 \text {. Japanese UN mandate } 1919 \text {, US } \\
\text { administration } 1947 \text { as part of the Trust } \\
\text { Territory of the Pacific Islands }\end{array}$ & $\begin{array}{l}\text { Independent with } \\
\text { compact of free } \\
\text { association with } \\
\text { USA (1994) }\end{array}$ \\
\hline $\begin{array}{l}\text { Papua New } \\
\text { Guinea }\end{array}$ & $\begin{array}{l}\text { Acquired by Germany (New Guinea 1884) } \\
\text { and UK (Papua } 1884 \text { then to Australia } \\
\text { 1906). Australia full control of Papua } \\
\text { New Guinea } 1921 \text {. Japanese occupation } \\
\text { of most of the country 1942-1945. }\end{array}$ & Independent (1975) \\
\hline Pitcairn & $\begin{array}{l}\text { Early Polynesians became extinct prior to } \\
15 \text { th century. Mutineers from the Bounty } \\
\text { settled in } 1790 \text {. UK colony (1838). } 1856 \text {, } \\
\text { entire population emigrated to Norfolk, } \\
\text { but a small number returned to Pitcairn. }\end{array}$ & $\begin{array}{l}\text { British overseas } \\
\text { territory }\end{array}$ \\
\hline Rapa Nui & $\begin{array}{l}\text { European contact in } 1722 \text {; Peruvian slave } \\
\text { raids and disease greatly reduced popu- } \\
\text { lation to less than } 120 \text { in early } 1870 \text { s; } \\
\text { annexed by Chile }(1888)\end{array}$ & $\begin{array}{l}\text { Integrated within } \\
\text { Chile. Chilean } \\
\text { citizenship granted } \\
(1966)\end{array}$ \\
\hline Samoa & $\begin{array}{l}\text { British missionaries from 1830. Two civil } \\
\text { wars (1886-1894; 1898) reflecting West- } \\
\text { ern interests (Germany, UK and USA). } \\
\text { German Samoa annexed in } 1900 \text { under } \\
\text { Tripartite Agreement (1899), occupied } \\
\text { by New Zealand 1914-1962 (Western } \\
\text { Samoa Trust Territory). Pacifist Mau } \\
\text { resistance movement through 1900s. } \\
\text { Independent in 1962. Renamed Samoa } \\
1997 .\end{array}$ & Independent (1962) \\
\hline
\end{tabular}


Table 1.2 (Continued)

\begin{tabular}{|c|c|c|}
\hline Country & Comments on colonial history & $\begin{array}{l}\text { Present political } \\
\text { status }\end{array}$ \\
\hline $\begin{array}{l}\text { Solomon } \\
\text { Islands }\end{array}$ & $\begin{array}{l}\text { German protectorate over North Solo- } \\
\text { mons } 1886 \text { and British protectorate over } \\
\text { southern islands } 1893 \text {. German portion } \\
\text { transferred to UK } 1899 \text {. Occupied by } \\
\text { Japan } 1942 \text {. UK re-established } 1945 \text {. Self- } \\
\text { government } 1976 \text {. }\end{array}$ & Independent (1978) \\
\hline Tokelau & $\begin{array}{l}\text { Missionaries from 1845, Peru slave raid- } \\
\text { ers } 1863 \text {, British protectorate after } 1977, \\
\text { annexed by UK and included as part of } \\
\text { Ellice Islands } 1916 . \text { Placed under New } \\
\text { Zealand administration } 1925 . \text { Became } \\
\text { incorporated into New Zealand } 1949 .\end{array}$ & $\begin{array}{l}\text { Part of New } \\
\text { Zealand with } \\
\text { self-governing } \\
\text { legislature (1996) }\end{array}$ \\
\hline Tonga & $\begin{array}{l}\text { Missionaries from } 1797 \text {. Unified under } \\
\text { Tāufa'āhau in } 1845 \text { as a constitutional } \\
\text { monarchy (constitution granted in } 1875 \text { ). } \\
\text { Self-governing as a British protected state } \\
\text { from } 1900\end{array}$ & $\begin{array}{l}\text { End of protected } \\
\text { status - fully inde- } \\
\text { pendent (1970) }\end{array}$ \\
\hline Tuvalu & $\begin{array}{l}\text { Ellice Islands declared a British Protector- } \\
\text { ate in } 1892 \text { as part of British Western } \\
\text { Pacific Territories, then as Gilbert and } \\
\text { Ellice Islands from } 1916 \text { to } 1974 \text {. Voted } \\
\text { for independence as Tuvalu, separate from } \\
\text { Gilbert Islands (Kiribati), in 1974. }\end{array}$ & Independent (1978) \\
\hline Vanuatu & $\begin{array}{l}\text { Labour 'blackbirding' and missionaries } \\
\text { from } 1860 \text { s. France and UK 'joint naval } \\
\text { commission' } 1887 \text { to protect expatriates } \\
\text { but no jurisdiction over indigenous inhab- } \\
\text { itants. France and UK declared a 'condo- } \\
\text { minium' } 1906 \text {. Confused administration } \\
\text { with dual colonial systems. }\end{array}$ & Independent (1980) \\
\hline $\begin{array}{l}\text { Wallis and } \\
\text { Futuna }\end{array}$ & $\begin{array}{l}\text { First European settlers } 1837 \text {, local trea- } \\
\text { ties established French protectorate in } \\
\text { Uvea (Wallis) } 1887 \text { and } 1888 \text { (Futuna } \\
\text { and Alofi). Annexed as colony } 1917 \text { and } \\
\text { under authority of New Caledonia. 1961- } \\
\text { 2003 French overseas territory. }\end{array}$ & $\begin{array}{l}\text { French overseas col- } \\
\text { lectivity }(2003)\end{array}$ \\
\hline
\end{tabular}

Source: Expanded and adapted from Murray and Overton (2015: 355)

was seized, and people displaced. In others, there was profound change in Pacific cultures due to the introduction of Christianity, wage labour, diseases and new material goods. In Fiji, Aotearoa/New Zealand, New Caledonia and French Polynesia, new populations from Europe and Asia were settled alongside Pacific societies, with major implications for national identity. In these places, colonialism was dominant, visible and disruptive. Yet, in many rural regions of some territories such as Papua New Guinea, Solomon Islands and parts of Vanuatu, daily life carried on largely as if colonial rule 
did not exist. Indeed, only with the Second World War and the ousting or threatening of the colonial powers by Japan, was there any major visible presence and disturbance of daily life for a significant proportion of the region's population.

The era of formal colonialism in the Pacific lasted until the 1960s by which time colonialism had become consolidated in general terms. There were a number of major events during this period that were of influence and which rendered the colonial map ever-more differentiated. The First World War saw the end of formal German colonies in the region, with German Western Samoa being occupied by New Zealand on behalf of the British Empire in 1914. The remaining German protectorates including New Guinea and parts of Melanesia were formally handed over with the Treaty of Versailles in 1919. Many of the Japanese controlled territories of the early 20th century were transferred to the USA following defeat in the Second World War. Given the declining relative influence of Great Britain following this latter war, and to a lesser extent France, the USA rose to assume both political and economic power motivated in large part by Cold War politics of the post1945 period. New Zealand and Australia inherited some of the influence over various territories and countries that Great Britain left behind during second half of the 20th century.

To an extent the colonial powers prepared some parts of the Pacific Islands for independence in the post-Second World War period, by recognising, protecting and incorporating elements of indigenous authority into the state's ruling institutions. Thus, in Fiji, selected chiefs became agents of the colonial state, left largely to control indigenous Fijian lands and villages, and in Tonga the royal family and associated nobles received British protection. These were examples, common throughout many parts of the Pacific, of a policy of 'colonial conservation': the maintenance, even strengthening, of a local political and social elite left largely in control of local populations while the European colonial powers managed the commercial and urban sectors more directly. Arguably this was a form of local sovereignty that was protected and nurtured (arguably even created) by the colonial states, albeit a form that ossified social hierarchies and limited the opportunities for social and economic mobility.

When independence did begin to appear in the Pacific Islands, it eventuated later than other waves of decolonisation across the world. This can be explained by debates concerning national viability (for smaller territories), lack of cohesion and potential conflict amongst diverse populations (Fiji, Vanuatu, Papua New Guinea) and the important role that some colonies and territories played during the Cold War (French Polynesia and the American Micronesian territories especially). Colonies that moved to full independence included Samoa (1962), Nauru (1968), Fiji (1970), PNG (1975), Solomon Islands (1978), Kiribati (1979), and Vanuatu (1980) (see Table 1.2). Tonga, which had been a protectorate of Britain, withdrew from this arrangement to assume full independence in 1970 . 
Given the strategic role of the region and viability issues, models of semiautonomy and other sovereignty arrangements were developed in the Pacific that at the time were unique to the world. In fact, these models were very similar to paths chosen by many other colonised islands in the Caribbean and the Atlantic and these models of unique sovereignty arrangement remain in place or continue to evolve until today - something we will explore further in Chapter 4. For example, the Cook Islands and Niue obtained 'selfgoverning in free association' status with New Zealand in 1965 and 1974 respectively. This sees the latter responsible for defence and much foreign and monetary policy while inhabitants of these countries have citizenship in New Zealand. More recently, in what we later discuss as 'retroliberalism' harking back to the classic liberalism of the early 19th century - the New Zealand government has begun to refer to these territories together with fully dependent Tokelau, and other smaller islands and atolls as the New Zealand 'realm' (see Box 2.1). In the case of the USA, various 'compact in free association' agreements were reached with the Marshall Islands (1986), FSM (1986) and Palau (1994) - territories that were administered as United Nations trusts following the Second World War and during the height of the Cold War (see Box 3.4). Dependent status as 'unorganised territories' was developed in American Samoa and Guam which continue to play important military roles in the Pacific region for the USA. France - and many inhabitants of its territories - have been reticent to let go of its colonial status, despite pressure to do so both from the UN Special Committee on Decolonization and indigenous peoples of the territories. This has resulted in significant conflicts and independence movements in French Polynesia and New Caledonia particularly. The former played a very important role during the Cold War when nuclear tests were undertaken in the small atolls of the territory. The latter has one of the world's largest nickel deposits which have provided an important mineral wealth resource for export. Each of the French territories has had several different official statuses.

There are also territories that have remained fully incorporated into the administrative structures of the colonial power. Hawaici, for example, was originally a Polynesian monarchy which was overthrown by American capitalist elites in order to maximise the gains of fruit and other exports. It became an official US colony from 1898 and incorporated as a state in 1959 becoming the 50th and newest of all the United States. Rapa Nui has also been fully incorporated to one extent or another over time following its annexation by Chile in 1888 after Europeans, including Scottish sheep farmers, had abandoned their economic interests. The current status of Rapa Nui as a provincia (the second tier in a four-tier spatial government system) in Region V of Chile is significant and came following the end of the Pinochet dictatorship in 1990 during which it was at the lower rank of comuna. Compared to other provinces, the population of the territory is very small and thus it wields relatively large influence within Chile. Despite a visible independence movement there is little prospect of change in the 
future, especially given recent expansion of what the central government has termed 'concessions' under Bachelet (2014-2018).

However, as we discuss in Chapter 4, the story of decolonisation in the Pacific Islands is not simply a matter of an inevitable trajectory from colonial rule to full independence. Many countries have followed this path yet others appear to remain stalled (Robie 1989), paused (Connell 1988, 1993), or under continuous renegotiation (Baldacchino 2010). To some, incomplete decolonisation appears to be the result of colonial powers being reluctant to leave - such has been the narrative of many for New Caledonia/Kanaky for example. However, there are also examples of Pacific peoples themselves being reluctant to shed strong ties with their metropolitan 'patrons'. Tokelau has rejected a degree of independence in two referenda, the result of New Zealand being pressured by the UN Special Committee on Decolonization (see Box 4.2). In various other territories (Rapa Nui, Wallis and Futuna, Guam, American Samoa for example) there does not seem to be a strong push for full independence despite some groups advocating this. Indeed, there are some examples of resistance to further decolonisation; in an interesting example of domestic inter-island rivalry, groups in the Marquesas Islands of French Polynesia have stated that, if the Tahitian independence movement was to get its way, it would seek to split from Tahiti and retain a status as a French territory.

There are good reasons for many Pacific islands to seek to maintain ties with the metropole. Beginning with independence and the postcolonial period, there has been a relatively large-scale migration of Pacific Island peoples to the Pacific Rim and beyond - especially to New Zealand, Australia and, to an extent, the USA and France. The remittances sent by migrants back to their homelands combined with high per capita levels of aid and associated government employment and bureaucracy led to the characterisation of the microstates of the postcolonial Pacific as comprised to lesser or greater degree by MIRAB economies. ${ }^{7}$ Remittances have continued through the generations, and although some migrant flows have been stemmed recently, third and fourth generations continue to send high levels of per capita remittances by global standards. To varying degrees, these MIRAB economies are predicated on maintaining constitutional arrangements that link them to their former or present colonial metropoles. For many fully independent Pacific states, the options for migration and remittances - and for high aid levels - are much more constrained. As we discuss at length further in this book, although aid has ebbed and flowed it has remained very high in per capita global terms. As a consequence, the power of donors has remained significant, calling into question the ostensible sovereignty of a number former colonies and semi-autonomous territories.

Political sovereignty, then, is varied and relates to different economic strategies being pursued by a very diverse range of Pacific states. However, sovereignty seems to have an increasingly economic dimension. The arrival of a period driven by neoliberal policies in the 1980s (see Chapter 2) has 
caused some commentators to reflect on the economic and political sovereignty or otherwise of the Pacific Island countries and territories. As we explore in the next two chapters, strict conditionalities applied to aid and loans in the 1980s and 1990s attempted to impose neoliberal solutions for the Pacific Island economies, both independent and otherwise. Apart from the evolution of some export-oriented labour - or environmentallyintensive industries such as garments and agro-food exports in some of the larger economies, it has proven very difficult to obtain sustainable outwardoriented economic development. In fact, such developments have often been reliant on trade preferences which have been gradually withdrawn under the past two decades of WTO-inspired and enforced free market trade reform. Only tourism has provided sustainable economic opportunities, although the control and flow of profits is not always retained within the island economies themselves and the broader costs to sustainability can often be substantial. According to Firth, this period of globalisation, beginning in the late 1980s and early 1990s, represented a consolidation of weakened national sovereignty in the Pacific despite political independence:

Just as the place of the Pacific Islands in the first globalisation was to be subordinate to the temperate, developed world, so their place in the second globalisation is also to be subordinate, this time to a set of international institutions that have set the rules of the global economy. The new globalization now combined with independent sovereign rule, means incorporation into the global economy on terms that suit the interests of the financial markets, the aid donors, and those relatively few Pacific Islanders who are in a position to benefit from this situation.

(Firth 2000: 191)

This complex colonial and postcolonial political and economic history has, as already noted, given rise to a wide range of formal arrangements and actual outcomes in terms of the sovereignty of the region. The process of decolonisation has been partial and diverse. There have been conflicts in the French territories, and to an extent the conflicts of Melanesia (such as Bougainville and the Solomon Islands) come as consequences of the long-term unfolding of colonialism in the region and in particular the creation of independent nation states that retain diverse ethnicities in ways that perpetuate precolonial struggles. It is perhaps not surprising that such postcolonial internal and regional conflicts have occurred in countries that had experienced only a thin veneer of colonial rule and where attempts to establish a single national identity and polity were largely unsuccessful. In contrast, as we have seen in the case of some territories such as Tokelau, there have been continued calls from the indigenous population to retain constitutional ties to the colonial metropole. In this sense formal measures of independence do not tell us the full story of sovereignty - it is fluid, negotiated and more difficult to measure than legal statuses and recognised histories might suggest. 
Indeed, a central argument in this book is that sovereignty is as much about the day-to-day performance of political freedoms, independence and selfdetermination as it about such formal arrangements. Sovereignty is about agency as much as it is about structure.

The relationships between former colonies and the colonial powers remains deeply intertwined, variable, dynamic and complex. Therefore, the postcolonial landscape is one where a variety of institutions and individuals interact in multifaceted ways. Relationships occur at many levels, not just between the nation-states. This, and perhaps every, colonial and postcolonial moment is not monolithic - a concept we referred with reference to historic patterns as polycolonialism, but which may also be extended to the present array of arrangements regarding independence and sovereignty (see Chapter 7). Global structures, signals and flows are interpreted, ignored, adjusted and reformed by agency on the ground. Relationships are numerous, complex, multifaceted and two-way: 'colonialism' (defined broadly as the deliberate interpenetration of one system by another in search of material or other advantage) thus occurs in many forms. This involves much more holistic and flexible performances of sovereignty that go beyond formal constitutional arrangements and that ultimately, in the day-to-day affairs of the region, are of at least as much influence.

\section{Researching aid in the Pacific}

This book explores the complexities of sovereignty in the Pacific through the workings of international development aid. It analyses the inverse sovereignty hypothesis posited earlier in this chapter. Does the aid regime of the first decade of the 21st-century result in diminished sovereignty of small and overstretched Pacific island states, despite its rhetoric of country ownership and donor alignment and harmonisation? We do this by developing three 'vertical' themes and questions through subsequent chapters: (1) how do size and scale affect the ability of Pacific states to engage effectively with aid donors and secure benefits from aid? (2) to what extent does political status relate to the ability to establish policy sovereignty? and (3) what 'cultures' of aid - in terms of official and unofficial policies and practices - have developed and how can these help secure policy sovereignty - agency by Pacific islands - in the region?

With support from New Zealand's Marsden Fund, a three-year research project took place largely from 2011-2014, with ongoing work undertaken since that date. Thesis work by Nicki Wrighton $(\mathrm{PhD})$ and Avataeo Junior Ulu (Masters) and several others combined with the research work of the academic staff (Overton, Murray and Prinsen). Several country case studies were conducted, particularly focusing on the policies and practices of local aid offices and officials, together with an overview of aid volumes and policies in the region. For case studies in the Francophone territories, we received funding from France's Fonds Pacifique. Subsequent funded research 
work on migration and education in the Pacific has allowed some continued indirect engagement with a number of the locations and themes addressed in this book.

Although the project began with a plan to choose certain country case studies to cover a range of countries in terms of size and political status, a key principle from the outset that the work had to involve the active participationand decision to participate - of Pacific individuals and offices. This guided the central research of Wrighton in particular who went to considerable lengths to explain her work then ask individuals and departments to join or not if they wished. It was an 'opt-in' principle and there was a strong wish not to contribute to the pressures on officials that Wrighton had noted earlier. Fortunately, officials in several countries were keen to participate and asked to join and were active and forthcoming in expressing their views and telling their stories. Through Wrighton's work and that of others on the broader team (the supervision of Suaalii-Sauni and the master's and doctoral research of Mountfort, Kiddle, Broadbent, Geary Nichol, Talagi, Thoma, Christ and Pirnia) we were able to compile a set of country-based material (Tuvalu, Cook Islands, Vanuatu, Samoa, Tonga, New Caledonia, Wallis and Futuna, Niue, Solomon Islands). We draw on this work both throughout the text of this book and also through a series of 'research insights' boxes. The latter also include contributions from colleagues from throughout the region (Aiafi, Sisifa, Blaise, Mawyer and Taumeofolau) who we met and who challenged and extended our understandings of aid and sovereignty in the Pacific.

Despite the enthusiastic involvement of many Pacific Island participants, the research team remained a group of largely palagi (European) researchers based in New Zealand. Many of the team had much experience in the region, some could converse in Samoan, bislama, French or Spanish and others spent time working in local institutions. But the view is still largely that of outsiders. This has some advantages, in terms of the ability to retain a more detached global perspective on the issues, yet we could not possibly gain the sorts of relationships, insights and understandings that Pacific Island researchers could.

Overall, the methodological approach of the research was varied. We adopted a quantitative approach for the analysis of aid statistics and policies. Yet, for much of the work, we recognised the importance of the way participants gave meaning and expression to their own experiences. This recognised a more constructivist epistemology, one that recognised that different ways of knowing and communicating knowledge exist in the region (Gegeo 1998; Gegeo and Watson-Gegeo 2001). Qualitative approaches, through the use particularly of in-depth semi-structured interviews and discussions, coupled with observation, often participant observation, were effective in allowing participants to talk widely and freely, and in many instances steer the direction and tone of the conversations. Whilst not explicitly adopting Pacific methodologies, such as talanoa (for example Vaioleti 2006; Prescott 2008; Farrelly and Nabobo-Baba 2014; Suaalii-Sauni and Aiolupotea 2014), 
we recognised that value of developing relationships through talking in a relaxed and appropriate manner.

Over the three years of the project, the central concern of the project - the inverse sovereignty effect - was questioned and adjusted. We soon found that this hypothesis gave us only a partial and sometimes misleading view of aid and aid relationships. Instead we identified and explored a sort of 'perverse' or 'reverse' sovereignty effect. Yes, we could see that the top-down compliance burdens of the new conditionalities were undermining policy sovereignty in many instances but there were also many instances of astute bottom-up strategies and practices being used to resist or reshape the nature of external control and influence. Pacific island officials were far from passive or powerless in aid relationships and, in fact, we saw many cases where the Paris Declaration principles were being followed and driven from within the region.

Overall, we reject some previous attempts to frame aid in the Pacific either as strongly negative (pace Helen Hughes) or marked by a simple dichotomy between dominant powerful donors and weak and passive recipients. It is the complexity and variability in practices and attitudes that we highlight, and it is in the niches and fissures of personalities, everyday practices and manifold interactions that we see the real exploration and exercise of agency by Pacific actors, expressing policy sovereignty. Nonetheless, we also return to the importance of formal and material aspects of the aid sector. Agreements, policies, statistics, review documents and signed memoranda of understanding are all important in giving substance to what is discussed, negotiated and contested.

The study is not concerned with grand theories or prescriptive approaches. We are not trying to define what is 'good aid' or appropriate sovereignty for Pacific peoples. Rather this is a largely descriptive and analytical study focused on policy, practice and the operational aspects of aid in the Pacific islands: we emphasise local agency, capabilities and resources. We aim to gather and compile ideas and examples from the region and globally to help inform how ownership/sovereignty can be given substance in the region and bring the improvements to their lives that Pacific peoples seek. Whilst focusing on the inverse sovereignty hypothesis, we are also mindful, following Hau'ofa, Helu Thaman and other Pacific scholars, of the need to be critical of academic frames of development which portray Pacific peoples simply as vulnerable, constrained, passive and powerless (Hau'ofa 1983; Thaman 1993). Thus, as well as being concerned with the way external agencies are imposing conditions and burdens on Pacific institutions and officials through the aid regime, we are keen to uncover ways in which Pacific people exercise appropriate agency in the aid world.

The book begins in the next chapter with a review of the global aid environment. Although our focus is on the period approximately between the years 2000 and 2010, marked by the overriding influence of the MDGs and the Paris Declaration, we place this period in the context of previous aid 
'regimes', such as the neoliberalism of the 1980s and 1990s, and the more recent opening up of a 'retroliberal' era. Chapter 3 then paints a picture of aid in the Pacific, mapping volumes and flows of official aid over time and identifying key donors and recipients. It also attempts to place these aid flows against other forms of development assistance, such as trade preferences and migration concessions. We then seek in Chapter 4 to analyse in greater detail what is meant by sovereignty in relation to development aid. This begins with a review of conventional definitions of state sovereignty before exploring the way sovereignty is played out in Pacific island states in particular ways. This sees both a strongly island-centric and terrestrial view of sovereignty - bounded, competitive, territorial, yet contestable and tradable - and a more oceanic view, one that stresses fluidity, mobility, interaction and multiple identities.

In Chapter 5 we move explicitly to the inverse sovereignty hypothesis and assemble evidence of the way donor conditionalities combine with limited local capacity to produce often serious pressures that undermine the ability of local agencies to manage their own development effectively. However, Chapter 6 then examines the many ways in which Pacific Island agents and institutions are developing strategies and tactics to combat these pressures. This is a reverse effect, evidence of the assertion of policy sovereignty through a wide variety of policies, practices, relationships and negotiations. This demonstrates the ways in which many Pacific Island leaders and bureaucrats have proved very adept at engaging with the global aid regime and using it, through locally-adapted systems and social norms, to leverage important local gains and resist unpalatable external demands. Finally, in the concluding chapter, we attempt to pull the thematic strands of the book together, returning to our original questions and hypothesis. We also attempt to present some practical suggestions - drawn from exemplars throughout the region - for ways in which development sovereignty can be strengthened in the Pacific and help achieve the development aspirations of Pacific people.

\section{Notes}

1 Throughout this book 'island states' refers to independent island state nations (such as Fiji), and 'territories' refers to metropolitan overseas territories of which there is a range of types as we discuss elsewhere.

2 Tables 1.1 and 1.2 list island states and territories that we consider to be part of the Pacific Islands. We are aware that this is a subjective selection. We include Hawai' $i$ and New Zealand, for example, because of their high proportional Pacific Island or Pacific Island-descended populations and their deep historical connections to the region.

3 Official Development Assistance as measured by the OECD. Negative values represent a net donor.

4 "Tino rangatiratanga" translates literally as "absolute chieftanship or full chiefly authority." However, in contemporary Aotearoa society it is more broadly defined as "the power to be self-determining" (Fleras and Spoonley 1999: 27). 
5 This term is intended to counteract a monolithic view of colonialism that unfolds in a uniform way across the region. Similarly it could be argued that the decolonisation process, which is also highly complex and ongoing, has led to complex geographies of sovereignty, representing an extension of this earlier polycolonial process.

6 Processes such as those outlined here resonate with the later concept of the aid regime of 'retroliberalism' explored in chapter 2 which has state sponsored mercantilism at its core.

7 The acronym MIRAB refers to economies shaped by Migration, Remittances, Aid and Bureaucracy (Bertram and Watters 1985 - see Box 2.2). 


\section{References}

ABC (2016) 'PNG's plan to hire Cuban doctors criticised amid budget cuts', www.abc.net.au/news/2016-11-25/png-looks-to-cuban-doctors-to-fix-rural-health/8058338, accessed 20 December 2016.

ADB (2014) 'Key indicators for Asia and the Pacific 2014', www.adb.org/publications/keyindicators-asia-and-pacific-2014, accessed 10 June 2016.

ADB (2016) 'ADB Sovereign projects 2016', www.adb.org/projects/, accessed 11 May 2016. Agg, C. (2006) Trends in Government Support for Non-Governmental Organizations: Is the "Golden Age" of the NGO Behind Us?, Geneva, UNRISD.

Agnew, J. (2009) Globalization and Sovereignty, Lanham, Rowman \& Littlefield Publishers. Aiafi, M. A. P. R. (2016) 'Public policy processes in the Pacific Islands: A study of policy initiation, formulation and implementation in Vanuatu, the Solomon Islands, Samoa and regional inter-governmental organisations', unpublished PhD thesis, Wellington, Victoria University of Wellington.

Alfini, N. and Chambers, R. (2007) 'Words count: Taking a count of the changing language of British aid', Development in Practice, 17(4-5), 492-504.

Allen, T. and Stremlau, N. (2005) 'Media policy, peace and state reconstruction', Discussion Paper No. 8, London, Crisis States Research Centre, London School of Economics.

American Samoa Government (2014) American Samoa Statistical Yearbook 2014, Pago Pago, Department of Commerce, Statistical Division.

Anders, M. (2016) 'ODA redefined: What you need to know', Devex, www.devex.com/news/odaredefined-what-you-need-to-know-87776, accessed 29 July 2016.

Anderson, T. (2008) The Limits of RAMSI, Sydney, AID/WATCH.

Anderson, T. and Lee, G. (eds.) (2010) In Defence of Melanesian Customary Land, Sydney, AID/WATCH.

Angelo, A. (1997) 'Tokelau: The last colony?', New Zealand Studies, 7(3), 8-12.

Angelo, A. (2002) 'To be or not to be ...: Integrated, that is the problem of islands', Revue Juridique Polynesienne, 2, 87-108.

Armitage, D. (2005) 'The contagion of sovereignty: Declarations of independence since 1776', South African Historical Journal, 52(1), 1-18.

Armon, J. (2007) 'Aid politics and development: A donor perspective', Development Policy Review, 25(5), 653-656.

Asante, A. D. , Negin, J. , Hall, J. , Dewdney, J. and Zwi, A. B. (2012) 'Analysis of policy implications and challenges of the Cuban health assistance program related to human resources for health in the Pacific', Human Resources for Health, 10, 10.

AusAID (2001) Reducing Poverty: The Central Integrating Factor of Australia's Aid Program, Canberra, Australian Agency for International Development.

Australian Overseas Aid Program (1997) One Clear Objective: Poverty Reduction through Sustainable Development, Canberra, Australian Agency for International Development. Australian Overseas Aid Program (1998) Australia and Pacific Island Countries: Partners in Development, Canberra, Australian Agency for International Development.

Bahn, P. G. and Flenley, J. (1992) Easter Island Earth Island, London, Thames and Hudson.

Baldacchino, G. (2006a) 'Managing the hinterland beyond: Two ideal-type strategies of economic development for small island territories', Asia Pacific Viewpoint, 47(1), 45-60.

Baldacchino, G. (2006b) 'Innovative development strategies from non-sovereign island jurisdictions? A global review of economic policy and governance practices', World Development, 34(5), 852-867.

Baldacchino, G. (2010) Island Enclaves: Offshoring Strategies, Creative Governance, and Subnational Island Jurisdictions, Montreal, McGill-Queen's University Press.

Baldacchino, G. and Hepburn, E. (2012) 'A different appetite for sovereignty? Independence movements in subnational island jurisdictions', Commonwealth \& Comparative Politics, 50(4), 555-568.

Baldacchino, G. and Milne, D. (2006) 'Exploring sub-national island jurisdictions: An editorial introduction', The Round Table, 95(386), 487-502.

Ball, M. M. (1973) 'Regionalism and the Pacific Commonwealth', Pacific Affairs, 46(2), 232-253.

Banks, G. , Murray, W. E. , Overton, J. and Scheyvens, R. (2012) 'Paddling on one side of the canoe? The changing nature of New Zealand's development assistance programme', 
Development Policy Review, 30(2), 169-186.

Barcham, M. , Scheyvens, R. and Overton, J. (2009) 'New Polynesian triangle: Rethinking

Polynesian migration and development in the Pacific', Asia Pacific Viewpoint, 50(3), 322-337.

Barker, J. (1995) 'For whom sovereignty matters', in Barker, J. (ed.) Sovereignty Matters:

Locations of Contestation and Possibility in Indigenous Struggles for Self-Determination,

Lincoln, University of Nebraska Press, 1-31.

Barnett, J. and Campbell, J. (2010) Climate Change and Small Island States: Power,

Knowledge, and the South Pacific, London, Earthscan.

Batibasaqa, K. , Overton, J. and Horsley, P. (1999) 'Vanua: Land, people and culture in Fiji', in Overton, J. and Scheyvens, R. (eds.) Strategies for Sustainable Development: Experiences from the Pacific, London and New York, Zed Books, 100-108.

Bedford, C. , Bedford, R. and Ho, E. (2010) 'Engaging with New Zealand's recognized seasonal employer work policy: The case of Tuvalu', Asian and Pacific Migration Journal, 19(3), 421-445. Bedford, R. , Bedford, C. , Wall, J. and Young, M. (2017) 'Managed temporary labour migration of Pacific Islanders to Australia and New Zealand in the early twenty-first century', Australian Geographer, 48(1), 37-57.

Beeson, M. (2003) 'Sovereignty under siege: Globalisation and the state in Southeast Asia', Third World Quarterly, 24(2), 357-374.

Bertram, I. G. (1986) '“Sustainable development” in Pacific micro-economies', World Development, 14(7), 809-822.

Bertram, I. G. (1993) 'Sustainability, aid, and material welfare in small South Pacific Island economies, 1900-1990', World Development, 21(2), 247-258.

Bertram, I. G. (2004) 'On the convergence of small island economies with their metropolitan patrons', World Development, 32(2), 343-364.

Bertram, I. G. (2006) 'Introduction: The MIRAB model in the twenty-first century', Asia Pacific Viewpoint, 47(1), 1-13.

Bertram, I. G. and Watters, R. F. (1985) 'The MIRAB economy in South Pacific microstates', Pacific Viewpoint, 26(3), 497-519.

Bertram, I. G. and Watters, R. F. (1986) 'The MIRAB process: Earlier analyses in context', Pacific Viewpoint, 27(1), 47-59.

Blok, P. and Molhuysen, P. (eds.) (1924) Nieuw Nederlandsch Biografisch Woordenboek (Vol. 6), Leiden, Sijthoff NV.

Bolton, L. (2003) Unfolding the Moon: Enacting Women's Kastom in Vanuatu, Honolulu, University of Hawai'i Press.

Braithwaite, J. , Dinnen, S. , Allen, M. , Braithwaite, V. and Charlesworth, H. (2010) Pillars and Shadows: Statebuilding as Peacebuilding in Solomon Islands, Canberra, Australian National University.

Brant, P. (2016) 'Mapping Chinese aid in the Pacific', in Powles, M. (ed.) China and the Pacific: The View from Oceania, Wellington, Victoria University Press, 173-175.

Brickenstein, C. (2015) 'Impact assessment of seasonal labor migration in Australia and New Zealand: A win-win situation?', Asian and Pacific Migration Journal, 24(1), 107-129.

Briguglio, L. (1995) 'Small island developing states and their economic vulnerabilities', World Development, 23(9), 1615-1632.

Broadbent, A. (2012) 'Power, media and development: A study of the Solomon Islands', unpublished Master of Development Studies thesis, Wellington, Victoria University of Wellington.

Brown, M. (2015) 'Te Mato Vai: Cook Islands-China and NZ Delivering Water to Rarotonga', presentation to 'China and the Pacific Conference: The View from Oceania', 25-27 February, Apia, www.victoria.ac.nz/chinaresearchcentre/programmes-and-projects/china-

symposiums/china-and-the-pacific-the-view-from-oceania/26-Hon-Mark-Brown-The-TripartiteChina,-NZ,-Cook-Islands-A-Cook-Island-Perspective.pdf, accessed 20 February 2016.

Brown, M. (2016) 'The tripartite China/NZ/Cook Islands project in the Cook Islands', in Powles, M. (ed.) China and the Pacific: The View from Oceania, Wellington, Victoria University Press, 201-207.

Brown, R. and Connell, J. (1993) 'The global flea market: Migration, remittances and the informal economy in Tonga', Development and Change, 24(4), 611-647.

Brown, W. (2010) Walled States, Waning Sovereignty, New York, Zone Books. 
Bryant-Tokalau, J. (2010) The Fijian Qoliqoli and Urban Squatting in Fiji: Righting an Historical Wrong?, Geelong, Alfred Deakin Research Institute, Deakin University.

Buiter, W. H. (2007) '“Country ownership": A term whose time has gone', Development in Practice, 17(4-5), 647-652.

Campbell, I. C. (1989) A History of the Pacific Islands, Christchurch, University of Canterbury Press.

Campbell, I. C. (1992) 'A historical perspective on aid and dependency: The example of Tonga', Pacific Studies, 15(3), 59-75.

Chile, L. (2006) 'The historical context of community development in Aotearoa New Zealand', Community Development Journal, 41(4), 407-425.

Choudry, A. and Kapoor, D. (eds.) (2013) NGOization: Complicity, Contradictions and Prospects, London, Zed Books.

Christ, K. G. (2012) 'Hakarongo mai! Rapanui women and decolonisation for development', unpublished Master of Development Studies thesis, Wellington, Victoria University of Wellington.

Connell, J. (1988) Sovereignty and Survival: Island Microstates in the Third World (No. 3), Sydney, Department of Geography, University of Sydney.

Connell, J. (1991) 'Island microstates: The mirage of development', The Contemporary Pacific, 3(2), 251-287.

Connell, J. (1993) 'Island microstates: Development, autonomy and the ties that bind', in Lockhart, D. G. , Drakakis-Smith, D. and Schembri, J. (eds.) The Development Process in Small Island States, London, Routledge, 117-147.

Connell, J. (2003) 'Losing ground? Tuvalu, the greenhouse effect and the garbage can', Asia Pacific Viewpoint, 44(2), 89-107.

Connell, J. (2008) 'Niue: Embracing a culture of migration', Journal of Ethnic and Migration Studies, 34(6), 1021-1040.

Connell, J. (2014) 'The two cultures of health worker migration: A Pacific perspective', Social Science \& Medicine, 116, 73-81.

Connell, J. (2016) 'Last days in the Carteret Islands? Climate change, livelihoods and migration on coral atolls', Asia Pacific Viewpoint, 57(1), 3-15.

Connell, J. and Brown, R. P. C. (2005) Remittances in the Pacific: An Overview, Manila, ADB. Cooke, B. and Kothari, U. (2001) Participation: The New Tyranny, London, Zed Books.

Coopmans, J. P. A. (1983) 'Het plakkaat van verlatinge (1581) en de Declaration of Independence (1776)', BMGN-Low Countries Historical Review, 98(4), 540-567.

Craig, D. and Porter, D. (2006) Development Beyond Neoliberalism? Governance, Poverty

Reduction and Political Economy, Abingdon and New York, Routledge.

Crocombe, R. G. (1972) 'Land tenure in the South Pacific', in Ward, R. G. (ed.) Man in the Pacific Islands, Oxford, Clarendon, 219-251.

Crocombe, R. G. (ed.) (1987) Land Tenure in the Pacific (3rd ed.), Suva, University of the South Pacific.

Crocombe, R. G. (1995) The Pacific Islands and the USA, Suva, Rarotonga and Honolulu, East West Center, Institute of Pacific Studies, University of the South Pacific and Pacific Islands Development Program.

Crocombe, R. G. (2007) Asia in the Pacific: Replacing the West, Suva, University of the South Pacific and Institute of Pacific Studies.

Crocombe, R. G. and Meleisea, M. (eds.) (1994) Land Issues in the Pacific, Christ-church, MacMillan Brown Centre for Pacific Studies, University of Canterbury.

Crowley, T. (1995) A New Bislama Dictionary, Suva, University of the South Pacific.

Curtain, R. , Dornan, M. , Doyle, J. and Howes, S. (2016) Pacific Possible: Labour Mobility: The Ten Billion Dollar Prize, Canberra, The World Bank and Australian National University.

DAC (n.d.) 'Definition of ODA',

www.oecd.org/dac/stats/officialdevelopmentassistancedefinitionandcoverage.htm\#Definition, accessed 9 September 2015.

DAC Secretariat (2016a) The Scope and Nature of 2016 HLM Decisions Regarding the ODAEligibility of Peace and Security-Related Expenditures, Paris, OECDDAC, www.oecd.org/dac/HLM_ODAeligibilityPS.pdf, accessed 15 May 2017.

DAC Secretariat (2016b) ODA Reporting of In-Donor Country Refugee Costs: Members' Methodologies for Calculating Costs, Paris, OECD-DAC, 
www.oecd.org/dac/stats/RefugeeCostsMethodologicalNote.pdf, accessed 15 May 2017.

Daes, E.-I. A. (2008) 'An overview of the history of indigenous peoples: Self-determination and the United Nations', Cambridge Review of International Affairs, 21(1), 7-26.

Daley, L. (2010) 'Hijacking development futures: "Land development" and reform in Vanuatu', in Anderson, T. and Lee, G. (eds.) In Defence of Melanesian Customary Land, Sydney,

AID/WATCH, 34-39.

De Carvalho, B. , Leira, H. and Hobson, J. M. (2011) 'The big bangs of IR: The myths that your teachers still tell you about 1648 and 1919', Millennium: Journal of International Studies, 39(3), 735-758.

DFAT (2014) Aid Program Performance Report 2013-14: Solomon Islands,

https://dfat.gov.au/about-us/publications/Documents/solomon-islands-appr-2013-14.pdf, accessed April 2016.

Dinnen, S. (2004) 'Lending a fist? Australia's new interventionism in the Southwest Pacific', State, Society and Governance in Melanesia, Discussion Paper 2004/5, Canberra, Research

School of Pacific and Asian Studies, Australian National University.

Dinnen, S. and Firth, S. (eds.) (2008) Politics and State Building in Solomon Islands, Canberra, Asia Pacific Press and Australian National University.

Dixon, M. (2006) 'Crime and justice', in Mulholland, M. and contributors, State of the Maori Nation: Twenty-First-Century Issues in Aotearoa, Auckland, Reed Publishing (NZ) Ltd, 189-203.

Dollar, D. and Pritchett, L. (1998) Assessing Aid: What Works, What Doesn't, and Why, Oxford, Oxford University Press.

Dommen, E. (1980) 'Some distinguishing characteristics of island states', World Development, 8(12), 931-943.

Downer, A. (1998) 'Australia and the Pacific Islands: Strategies for development: Speech by the Minister for Foreign Affairs The Hon: Alexander Downer MP' (transcript), Suva, Fiji, 17

December.

Dugay, C. (2015) 'What does Japan's new charter mean for development?', Devex, www.devex.com/news/what-does-japan-s-new-charter-mean-for-development-85595, accessed 16 December 2016.

Duncan, R. and Nakagawa, H. (2006) Obstacles to Economic Growth in Six Pacific Island Countries, Washington, DC, World Bank.

Dunn, L. (2011) 'The impact of political dependence on small island jurisdictions', World Development, 39(12), 2132-2146.

Durie, M. (1998) Te Mana, Te Kawanatanga: The Politics of Māori Self-Determination, Oxford, Oxford University Press.

Eaton, C. (1988) 'Vakavanua land tenure', in Overton, J. (ed.) Rural Fiji, Suva, Institute of Pacific Studies, University of the South Pacific, 19-30.

Ellis, F. (1985) 'Employment and incomes in the Fiji sugar economy', in Brookfield, H. C. , Ellis, F. and Ward, R. G. (eds.) Land, Cane and Coconuts, Canberra, Department of Human Geography, Research School of Pacific Studies, Australian National University, 65-110.

Escobar, A. (1995) Encountering Development: The Making and Unmaking of the Third World, Princeton, Princeton University Press.

Eyben, R. (2007) 'Harmonisation: How is the orchestra conducted?', Development in Practice, 17(4-5), 640-646.

Faleomavaega, E. (1994) 'American Samoa: A unique relationship in the South Pacific', in vom Busch, W. , Crocombe, M. T. , Crocombe, R. , Crowl, L. , Deklin, T. , Larmour, P. and Williams, E. W. (eds.) New Politics in the South Pacific, Rarotonga and Suva, Institute of Pacific Studies, University of the South Pacific, 113-122.

Farrelly, T. and Nabobo-Baba, U. (2014) ' Talanoa as empathic apprenticeship', Asia Pacific Viewpoint, 55(3), 319-330.

Ferguson, J. (2009) 'The uses of neoliberalism', Antipode, 41, 166-184.

Field, M. (2010) 'Samoan PM savages Air NZ', www.stuff.co.nz/travel/destinations/pacificislands/4338180/Samoan-PM-savages-Air-NZ, accessed 7 April 2017.

Firth, S. (2000) 'The Pacific Islands and the globalization agenda', The Contemporary Pacific, 12(1), 178-192.

Fisk, E. K. (1980) 'The island of Niue: Development or dependence for a very small nation', in Shand, R. T. (ed.) The Island States of the Pacific and Indian Oceans, Canberra, Development 
Studies Centre, Australian National University, 441-457.

Fleras, A. and Spoonley, P. (1999) Recalling Aotearoa: Indigenous Politics and Ethnic Relations in New Zealand, Auckland, Oxford University Press.

Fry, G. (1991) 'The politics of South Pacific regional cooperation', in Thakur, R. (ed.) The South

Pacific: Problems, Issues and Prospects, New York, St. Martin's Press, 169-181.

Fry, G. (1997) 'Framing the islands: Knowledge and power in changing Australian images of the South Pacific', The Contemporary Pacific, 9(2), 305-344.

Fry, G. (2015) 'Recapturing the spirit of 1971: Towards a new regional political settlement in the Pacific,' SSGM Discussion Paper 2015/3, Canberra, Australian National University.

Fukuyama, F. (1992) The End of History and the Last Man, New York, Avon Books.

Fullilove, M. (2006) 'RAMSI and state building in Solomon Islands', The Defender, Autumn, 31-35.

Furlong, K. and Hamano, A. (2014) Territorial Economic Accounts for American Samoa, the Commonwealth of the Northern Mariana Islands, Guam and the U.S. Virgin Islands, BEA Briefing Paper, Bureau of Economic Analysis, U.S., Department of Commerce, www.bea.gov/scb/pdf/2014/01\%20January/0114_territorial_economic_accounts.pdf, accessed 20 August 2016.

The Guardian (2015) 'PNG will cancel contracts of Australians advising government, says Peter O'Neill', www.theguardian.com/world/2015/jul/31/png-will-cancel-contracts-of-australiansadvising-government-says-peter-oneill, accessed 17 March 2017.

Geary Nichol, M. (2014) 'Principles in practice? Ownership in monitoring and evaluation in Vanuatu', unpublished Master of Development Studies thesis, Wellington, Victoria University of Wellington.

Gegeo, D. W. (1998) 'Indigenous knowledge and empowerment: Rural development examined from within', The Contemporary Pacific, 10(2), 289-315.

Gegeo, D. W. and Watson-Gegeo, K. A. (2001) "How we know": Kwara'ae rural villagers doing indigenous epistemology', The Contemporary Pacific, 13(1), 55-88.

Gibson, J. , Boe-Gibson, G. , Rohorua, H. T. S. and McKenzie, D. (2007) 'Efficient remittance services for development in the Pacific', Asia-Pacific Development Journal, 14(2), 55-74.

Gibson, J. and Mckenzie, D. (2012) 'The economic consequences of "brain drain" of the best and brightest: Microeconomic evidence from five countries', The Economic Journal, 122(560), 339-375.

Global Indigenous Caucus (2007) Report of the Global Indigenous Peoples' Caucus Steering Committee,

www.humanrights.gov.au/sites/default/files/content/social_justice/declaration/screport_070831.p df, accessed 15 June 2015.

Goldsmith, A. and Dinnen, S. (2007) 'Transnational police building: Critical lessons from TimorLeste and Solomon Islands', Third World Quarterly, 28(6), 1091-1109.

Gordenker, L. and Weiss, T. G. (1995) 'Pluralising global governance: Analytical approaches and dimensions', Third World Quarterly, 16(3), 357-388.

Gould, J. (2005) The New Conditionality: The Politics of Poverty Reduction Strategies, London, Zed Books.

Government of the Cook Islands (2011) Cook Islands Official Development Assistance Policy, Avarua, Government of the Cook Islands.

Government of the Cook Islands (2013) Government Financial Statistics,

www.mfem.gov.ck/economic-statistics/gov-fin-stats, accessed 20 December 2014.

Government of the Kingdom of Tonga (2010) Tonga Energy Road Map 2010-2020,

https://sustainabledevelopment.un.org/content/documents/1330tongaEnergy\%20Strategy.pdf, accessed 9 June 2017.

Government of Kiribati (2015) 'Development cooperation policy',

www.mfed.gov.ki/sites/default/files/Kiribati\%20Development\%20Cooperation\%20Policy.pdf, accessed 20 May 2017.

Government of Niue and Government of New Zealand (2011) 'Joint commitment between New Zealand and Niue 2011-2014', www.mfat.govt.nz/assets/_securedfiles/Aid-Prog-

docs/Commitment-for-Development/NZ-Niue-Joint-Commitment-for-Development-Niue.pdf, accessed 24 May 2017.

Government of Papua New Guinea (2008) 'Kavieng declaration on aid effectiveness: A joint commitment of principles and actions between the Government of Papua New Guinea and 
development partners', Port Moresby, Government of Papua New Guinea.

Government of Samoa (2010) Development Cooperation Policy: Partners in Development:

Promoting Aid Effectiveness, Apia, Ministry of Finance.

Government of Samoa and MFAT (2011) New Zealand-Samoa: Joint Commitment for

Development, Apia, Government of Samoa.

Grant, T. D. (1998) 'Defining statehood: The Montevideo Convention and its discontents',

Columbia Journal of Transnational Law, 37, 403-458.

Grynberg, R. (1993) 'Trade liberalisation in the post-Cold War era and its implications for the Fiji sugar industry', Journal of Pacific Studies, 17, 132-160.

Grynberg, R. (1995) The Impact of the Sugar Protocol of the Lomé Convention on the Fiji Economy, Economics Division Working Paper 95/8, Canberra, Research School of Pacific Studies, Australian National University.

Hadley, S. and Miller, M. (2016) PEFA: What Is It Good for? The Role of PEFA Assessments in Public Financial Management Reform, London, Overseas Development Institute, www.odi.org/publications/10403-pfm-public-finance-management-reform-pefa, accessed 15 May 2017.

Hagan, S. (1987) 'Race, politics, and the coup in Fiji', Bulletin of Concerned Asian Scholars, 19(4), 2-18.

Hameiri, S. (2007) 'The trouble with RAMSI: Re-examining the roots of conflict in Solomon Islands', The Contemporary Pacific, 19(2), 409-441.

Hameiri, S. (2012) 'Mitigating the risk to primitive accumulation: State-building and the logging boom in Solomon Islands', Journal of Contemporary Asia, 42(3), 405-426.

Hanks, M. F. (2011) 'Aid, sanctions and civil society: An analysis of the impacts of targeted sanctions on Fiji's non-governmental organisations', unpublished Master of Development Studies thesis, Wellington, Victoria University of Wellington.

Hardin, G. (1974) 'Lifeboat ethics: The case against helping the poor', Psychology Today, 8, 38-43.

Harvey, D. (2005) A Brief History of Neoliberalism, New York, Oxford University Press.

Hau'ofa, E. (1983) Tales of the Tikongs, Honolulu, University of Hawai'i Press.

Hau'ofa, E. (1993) 'Our sea of islands', in Waddell, E. , Naidu, V. and Hau'ofa, E. (eds.) A New

Oceania: Rediscovering Our Sea of Islands, Suva: University of the South Pacific, 1-16.

Hau'ofa, E. (2000) 'The ocean is us', in Hooper, A. (ed.) Culture and Sustainable Development in the Pacific, Canberra, Asia Pacific Press and Australian National University, 32-43.

Hau'ofa, E. (2008) We Are the Ocean: Selected Works, Honolulu, University of Hawai'i Press. Hayes, G. (1991) 'Migration, metascience, and development policy in island Polynesia', The Contemporary Pacific, 3(1), 1-58.

Hayward-Jones, J. (2014a) 'Australia's costly investment in Solomon Islands: The lessons of RAMSI', Lowy Institute Analysis, www.lowyinstitute.org/sites/default/files/hayward-

jones_australias_costly_investment_in_solomon_islands_0.pdf, accessed 17 March 2017.

Hayward-Jones, J. (2014b) 'Australia-Papua New Guinea emerging leaders dialogue:

Outcomes report', Lowy Institute Analysis,

www.lowyinstitute.org/sites/default/files/australia_png_emerging_leaders_dialogue_web_0.pdf, accessed 17 March 2017.

Helu, I. F. (1993) 'Identity and change in Tongan society since European contact', Journal de la Société des Océanistes, 97(2), 187-194.

Helu, I. F. (1994) 'Thoughts on political systems for the Pacific Islands', in vom Busch, W. , Crocombe, M. T. , Crocombe, R. , Crowl, L. , Deklin, T. , Larmour, P. and Williams, E. W. (eds.) New Politics in the South Pacific, Rarotonga and Suva, Institute of Pacific Studies, University of the South Pacific, 319-332.

Hendrikse, R. P. and Sidaway, J. D. (2010) 'Commentary', Environment and Planning A, 42, 2037-2042.

Hepburn, E. (2012) 'Recrafting sovereignty: Lessons from small island autonomies', in Gagnon, A. and Keating, M. (eds.) Political Autonomy and Divided Societies: Imagining Democratic Alternatives in Complex Settings, Basingstoke: Palgrave Macmillan, 118-133.

Herr, R. A. (1975) 'A minor ornament: The diplomatic decisions of Western Samoa at independence', Australian Journal of International Affairs, 29(3), 300-314.

Herr, R. A. (1986) 'Regionalism, strategic denial and South Pacific security', The Journal of Pacific History, 21(4), 170-182. 
Hintjens, H. and Hodge, D. (2012) 'The UK Caribbean overseas territories: Governing unruliness amidst the extra-territorial EU', Commonwealth \& Comparative Politics, 50(2), 190-225.

Hooper, A. (1993) 'The MIRAB transition in Fakaofo, Tokelau', Pacific Viewpoint, 34(2), 241-264.

Hooper, A. (2008) 'Tokelau: A sort of "self-governing" sort of "colony"', Journal of Pacific History, 43(3), 331-339.

Howe, K. R. (1984) Where the Waves Fall: A New South Sea Islands History from First Settlement to Colonial Rule (Vol. 2), Honolulu, University of Hawai'i Press.

Howell, J. and Lind, J. (2008) 'Changing donor policy and practice in civil society in the post9/11 aid context', Third World Quarterly, 30(7), 1279-1296.

Hughes, H. (2003) Aid has Failed the Pacific, Issue Analysis No. 33, Sydney, The Centre for Independent Studies.

Iati, I. (2010) Reconsidering Land Reform in the Pacific, Research Paper, Wellington, Council for International Development.

Iati, I. (2016) 'China in the Pacific: Alternative perspectives', in Powles, M. (ed.) China and the Pacific: The View from Oceania, Wellington, Victoria University Press, 128-138.

IEOM (2014) 'Nouvelle-Calédonie', Rapport Annuel 2013, Nouméa, Institut d'Emission de l'Outre-Mer (IEOM).

Ingersoll, K. A. (2016) Waves of Knowing: A Seascape Epistemology, Durham and London, Duke University Press.

ISEE (2013) Tableau de l'Economie Calédonienne, Nouméa, Institut de la Statistique et des Etudes Économiques Nouvelle Calédonie (ISEE), www.isee.nc/population/population.html, accessed 16 May 2017.

ISEE (2015) Tableau de l'Economie Calédonienne (version abrégée, 2015), Nouméa, Institut de la Statistique et des Etudes Économiques Nouvelle Calédonie (ISEE),

www.isee.nc/publications/tableau-de-l-economie-caledonienne-tec, accessed 16 May 2017.

Jacobs, A. C. (2016) 'Exploring the role of education in a MIRAB economy: Brain drain or brain gain? The case of Wallis and Futuna', unpublished Master of Development Studies thesis, Wellington, Victoria University of Wellington.

Jacobsen, T. , Sampford, C. and Thakur, R. (2008) Re-Envisioning Sovereignty: The End of Westphalia?, Aldershot, Ashgate Publishing Ltd.

JICA (2009) We Are Islanders! For the Future of the Pacific, www.jica.go.jp/english/publications/jica_archive/brochures/pdf/islanders.pdf, accessed 11 November 2016.

JICA (2010) 'Launch of the new JICA and Japan's ODA structure', www.iist.or.jp/wf/magazine/0734/pdf/100222-jica-oda-e.pdf, accessed 11 November 2016. Jotia, A. L. (2011) 'Globalization and the nation-state: Sovereignty and state welfare in jeopardy', US-China Education Review, 2, 243-250.

Kaufmann, D. , Kraay, A. and Zoido-Lobaton, P. (1999) Governance Matters, World Bank Policy Research Working Paper No. 2196, Washington, DC, World Bank.

Kelly, A. (2015) 'Restoring democracy: Australian responses to military coups in Fiji', Journal of International Studies, 11, 1-13.

Kiddle, F. B. (2014) 'A prologue to development: Establishing the legitimacy of the rule of law in post-conflict Solomon Islands', unpublished Master of Development Studies thesis, Wellington, Victoria University of Wellington.

Kidu, C. (2009) 'Maternal health in Papua New Guinea: Reality, challenges, and possible solutions', in Boston, J. (ed.) Eliminating World Poverty: Global Goals and Regional Progress, Wellington, Institute of Policy Studies, 179-186.

Knapman, B. (1987) Fiji's Economic History, 1874-1939: Studies of Capitalist Colonial Development, Pacific Research Monograph No. 15, Canberra, National Centre for Development Studies, Australian National University.

Kochenov, D. (2012) 'Dutch Caribbean territories facing EU law', West Indian Law Journal (Jamaica 50th jubilee special edn), 147-153.

Koeberle, S. and Stavreski, Z. (2006) 'Budget support: Concepts and issues', in Koeberle, S. , Stavreski, Z. and Walliser, J. (eds.) Budget Support as More Effective Aid, Washington, DC, World Bank, 3-27. 
Kothari, U. (ed.) (2005) A Radical History of Development Studies, London, Zed Books. Krasner, S. D. (2005) 'The case for shared sovereignty', Journal of Democracy, 16(1), 69-83. $\mathrm{Ku}, \mathrm{J}$. and Yoo, J. (2013) 'Globalization and sovereignty', Berkeley Journal of International Law, 31(1), 210-235.

Lal, B. V. (1986) 'Politics since independence: Continuity and change, 1970-1982', in Lal, B. V. (ed.) Politics in Fiji: Studies in Contemporary History, Sydney, Allen and Unwin, 74-106.

Lal, B. V. and Fortune, K. (2000) The Pacific Islands: An Encyclopedia (Vol. 1), Honolulu, University of Hawai'i Press.

Lal, B. V. and Pretes, M. (eds.) (2001) Coup: Reflections on the Political Crisis in Fiji, Canberra, Pandanus Books.

Larmour, P. (1997) 'Corruption and Governance in the South Pacific', State, Society and Governance in Melanesia, Discussion Paper 97/5, Canberra, Research School of Pacific and Asian Studies, Australian National University.

Larmour, P. (2002) 'Conditionality, coercion and other forms of "power": International financial institutions in the Pacific', Public Administration and Development, 22(3), 249-260.

Larmour, P. (2003) 'The foreignness of the state in the South Pacific', The New Pacific Review, 2(1), 24-33.

Larmour, P. and Barcham, M. (2005) 'National Integrity Systems in Small Pacific Island States', Policy and Governance Program, Discussion Paper 05-9, Canberra, Asia Pacific School of Economics and Government and Australian National University.

Legifrance (1789) Déclaration des Droits de l'Homme et du Citoyen de 1789, www.legifrance.gouv.fr/Droit-francais/Constitution/Declaration-des-Droits-de-l-Homme-et-duCitoyen-de-1789, accessed 30 July 2015.

Legifrance (1905) Loi du 9 Décembre 1905 Concernant la Séparation des Eglises et de l'Etat, Version consolidée au 19 mai 2011,

www.legifrance.gouv.fr/affichTexte.do?cidTexte $=$ LEGITEXT000006070169\&dateTexte $=200803$ 06, accessed 28 August 2015.

Leiva, F. (2008) 'Toward a critique of Latin American neostructuralism', Latin American Politics and Society, 50, 1-25.

Lewis, O. (2017) 'Advocates claim clearer guidelines needed for Recognised Seasonal Employer scheme worker deductions', Marlborough Express, 20 March 2017,

www.stuff.co.nz/business/farming/agribusiness/90611107/Advocates-claim-clearer-guidelinesneeded-for-RSE-worker-deductions, accessed 7 April 2017.

Liu, S. (2016) 'China's engagement with the South Pacific: Past, present and future', in Powles, M. (ed.) China and the Pacific: The View from Oceania, Wellington, Victoria University Press, 53-61.

Llewellyn-Fowler, M. and Overton J. (2010) 'Bread and butter human rights: NGOs in Fiji', Development in Practice, 20(7), 827-839.

Locke, K. (2015) 'NZ to assist Cuban medical programme in the Pacific', The Daily Blog, http://thedailyblog.co.nz/2015/02/23/nz-to-assist-cuban-medical-programmein-the-pacific/, accessed 20 December 2016.

Lockhart, D. G. , Drakakis-Smith, D. and Schembri, J. (eds.) (1993) The Development Process in Small Island States, London, Routledge.

Lotti, A. (2011) Le Statut de 1961 à Wallis et Futuna: Genèse de Trois Monarchies

Républicaines (1961-1991), Paris, Editions L'Harmattan.

Maaka, R. and Fleras, A. (2000) 'Engaging with indigeneity: Tino rangatiratanga in Aotearoa', in Ivison, D. , Patton, P. and Sanders, W. (eds.) Political Theory and the Rights of Indigenous Peoples, Oakleigh, Cambridge University Press, 89-109.

Maaka, R. and Fleras, A. (2005) The Politics of Indigeneity: Challenging the State in Canada and Aotearoa New Zealand, Dunedin, Otago University Press.

Mackintosh, H. (2011) Perspectives of Sovereignty in Aotearoa and the Pacific, Briefing Paper May 2011, School of Geography, Environment and Earth Sciences, Wellington, Victoria University of Wellington.

Mara, Ratu Sir K. (1997) The Pacific Way: A Memoir, Honolulu, University of Hawai'i Press. Marcus, G. E. (1993) 'Tonga's contemporary globalizing strategies: Trading on sovereignty amidst international migration', in Harding, T. and Wallace, B. (eds.) Contemporary Pacific Societies, Englewood Cliffs, NJ, Prentice Hall, 21-33. 
Marsters, E. , Lewis, N. and Friesen, W. (2006) 'Pacific flows: The fluidity of remittances in the Cook Islands', Asia Pacific Viewpoint, 47(1), 31-44.

Mawdsley, E. (2010) 'The non-DAC donors and the changing landscape of foreign aid: The (in)significance of India's development cooperation with Kenya', Journal of Eastern African Studies, 4(2), 361-379.

Mawdsley, E. , Murray, W. E. , Overton, J. , Scheyvens, R. and Banks, G. A. (2015) Sharing Prosperity? A Comparative Analysis of Aid Policy in New Zealand the United Kingdom in the 2010s, NZADDS Working Paper 2015(1), Wellington, NZADDS.

Mawdsley, E. , Murray, W. E. , Overton, J. , Scheyvens, R. and Banks, G. A. (2018) 'Exporting stimulus and "hared prosperity": Re-inventing aid for a retroliberal era', Development Policy Review, 36 O25-O43.

Mawdsley, E. , Savage, L. and Kim, S.-M. (2014) 'A "post-aid" world? Paradigm shift in foreign aid and development cooperation at the 2011 Busan High Level Forum', Geographical Journal, 180(1), 27-38.

May, R. J. (2003) 'Weak states, collapsed states, broken-backed states and kleptocracies: General concepts and Pacific realties', The New Pacific Review, 2(1), 35-58.

McCawley, P. (2010) 'Aid objectives: The hole in the aid review', Devpolicy Blog, http://devpolicy.org/aid-review-effectiveness20101125/, accessed 11 November 2016.

McCully, M. (2009). 'New Priorities for New Zealand Aid', Speech to the New Zealand Institute of International Affairs, 1 May http://www.national.org.nz/Article.aspx?ArticleID=29843, accessed 5 May 2009.

McElroy, J. L. (2006) 'Small island tourist economies across the life cycle', Asia Pacific Viewpoint, 47(1), 61-77.

McElroy, J. L. and Hamma, P. (2010) 'SITEs revisited: Socioeconomic and demographic contours of small island tourist economies', Asia Pacific Viewpoint, 51(1), 36-46.

McElroy, J. L. and Parry, C. (2012) 'The long-term propensity for political affiliation in island microstates', Commonwealth \& Comparative Politics, 50(4), 403-421.

McElroy, J. L. and Pearce, K. (2006) 'The advantages of political affiliation: Dependent and independent small-island profiles', Round Table, (386), 529-539.

McGregor, A. , Challies, E. , Overton, J. and Sentes, L. (2013) 'Developmentalities and donorNGO relations: Contesting foreign aid policies in New Zealand/Aotearoa', Antipode, 45(5), 1232-1253.

McMichael, P. (2017) Development and Social Change (6th ed.), Thousand Oaks, Pine Forge. Meerts, P. and Beeuwkes, P. (2008) 'The Utrecht negotiations in perspective: The hope of happiness for the world', International Negotiation, 13(2), 157-177.

Melbourne, H. (1995) Maori Sovereignty: The Maori Perspective, Auckland, Hodder Moa Beckett Publishers Ltd.

MFAT (2014a) Cook Islands, www.mfat.govt.nz/Countries/Pacific/Cook-Islands.php, accessed 28 August 2015.

MFAT (2014b) Recent Official Visits: Papua New Guinea to New Zealand, Wellington, Ministry of Foreign Affairs and Trade, www.mfat.govt.nz/en/countries-and-regions/pacific/papua-newguinea/, accessed 10 September 2016.

Moon, P. (2000) 'Maori sovereignty and concepts of state', He Tuhinga Aronui, 4, 46-59.

Morgan, M. G. and McLeod, A. (2006) 'Have we failed our neighbour?', Australian Journal of International Affairs, 60(3), 412-428.

Mountfort, H. (2013) 'An analysis of the aid effectiveness agenda in Tonga', unpublished Master of Development Studies thesis, Wellington, Victoria University of Wellington.

Mrgudovic, N. (2012a) 'Evolving approaches to sovereignty in the French Pacific', Commonwealth \& Comparative Politics, 50(4), 456-473.

Mrgudovic, N. (2012b) 'The French overseas territories in transition', in Clegg, P. and Killingray, D. (eds.) The NonIndependent Territories of the Caribbean and Pacific, London, Institute of Commonwealth Studies, University of London, 85-103.

Mugler, F. and Lynch, J. (eds.) (1996) Pacific Languages in Education, Suva, Institute of Pacific Studies, University of the South Pacific.

Munro, D. (1990) 'Transnational corporations of kin and the MIRAB system: The case of Tuvalu', Pacific Viewpoint, 31(1), 63-66.

Murray, W. E. (2001) 'The second wave of globalisation and agrarian change in the Pacific Islands', Journal of Rural Studies, 17(2), 135-148. 
Murray, W. E. and Overton, J. (2011a) 'Neoliberalism is dead, long live neoliberalism: Neostructuralism and the new international aid regime of the 2000s', Progress in Development Studies, 11(4), 307-319.

Murray, W. E. and Overton, J. (2011b) 'The inverse sovereignty effect: Aid, scale and neostructuralism in Oceania', Asia Pacific Viewpoint, 52(3), 272-284.

Murray, W. E. and Overton, J. (2015) Geographies of Globalization (2nd ed.), London, Routledge and Taylor and Francis.

Murray, W. E. and Overton, J. (2016a) 'Retroliberalism and the new aid regime of the 2010s', Progress in Development Studies, 16(3), 1-17.

Murray, W. E. and Overton, J. (2016b) 'Peripheries of neoliberalism: Impacts, resistance and retroliberalism as reincarnation', in Springer, S. , Birch, K. and MacLeavy, J. (eds.) Handbook of Neoliberalism, London, Routledge, 422-432.

Murray, W. E. and Storey, D. (2003) 'Political conflict in postcolonial Oceania', Asia Pacific Viewpoint, 44(3), 213-224.

Murray, W. E. and Terry, J. (2004) 'Niue's place in the Pacific', in Terry, J. and Murray, W. E. (eds.) Niue Island: Geographical Perspectives on the Rock of Polynesia, Paris, INSULA, UNESCO, 9-30.

Naidu, V. (2009) 'Changing gears on the Millennium Development Goals in Oceania', in Boston, J. (ed.) Eliminating World Poverty, Wellington, Institute of Policy Studies, 103-126.

Naidu, V. and Wood, T. (2008) A Slice of Paradise? The Millennium Development Goals in the Pacific: Progress, Pitfalls and Potential Solutions, Working Paper No. 1, Apia, Oceania Development Network, National University of Samoa.

Narayan, D. , Chambers, R. , Shah, M. K. and Petesch, P. (2000) Voices of the Poor: Crying Out for Change, Washington, DC and New York, World Bank Publications and Oxford University Press.

The National (2016) 'Cuban doctors for PNG', www.thenational.com.pg/cuban-doctors-png/, accessed 20 December 2016.

Negin, J. (2012) 'Cuba in the Pacific: More than rum and Coke', DevPolicy Blog, http://devpolicy.org/cuba-in-the-pacific-more-than-rum-and-coke-2-20120224/, accessed 20 December 2016.

New Zealand Foreign Affairs and Trade Aid Programme (2015a) New Zealand Aid Programme: Strategic Plan 2015-19, Wellington, Ministry of Foreign Affairs and Trade.

New Zealand Foreign Affairs and Trade Aid Programme (2015b) New Zealand Aid Programme: Investment Priorities 2015-19, Wellington, Ministry of Foreign Affairs and Trade.

New Zealand Foreign Affairs and Trade Aid Programme (2016) Evaluation of New Zealand's Development Cooperation in Tonga: Final Report, Wellington, Adam Smith International and MFAT.

New Zealand Parliament (2010) Ministerial Statements: UN Declaration on the Rights of Indigenous Peoples-Government Support, Wellington, New Zealand Parliament, www.parliament.nz/en-

nz/pb/debates/debates/speeches/49HansS_20100420_00000077/power-simon-ministerialstatements-\%E2\%80\%94-undeclaration-on, accessed $\overline{1} 3$ June 2016.

New Zealand Parliament, Foreign Affairs, Defence and Trade Committee (2010) Inquiry into New Zealand's Relationships with South Pacific Countries: Report of the Foreign Affairs, Defence and Trade Committee, Wellington, New Zealand House of Representatives.

Oberst, A. and McElroy, J. L. (2007) 'Contrasting socio-economic and demographic profiles of two, small island, economic species: MIRAB versus PROFIT/SITE', Island Studies Journal, 2(2), 163-176.

OECD (n.d.) 'In-donor refugee costs in ODA', www.oecd.org/dac/financing-sustainabledevelopment/In-donor-refugee-costs-in-ODA.pdf, accessed 16 December 2016.

OECD (2008) The Paris Declaration on Aid Effectiveness and the Accra Agenda for Action, Paris, OECD, www.oecd.org/dac/effectiveness/34428351.pdf, accessed 20 February 2014. OECD (2010) Paris Declaration Survey: Draft Summary of Progress, Nuku'alofa, OECD. OECD (2012) Better Aid: Aid Effectivness 2011: Progress in Implementing the Paris Declaration, Paris, OECD.

OECD (2015) OECD Development Co-operation Peer Reviews: New Zealand. Paris, OECD. Office of Insular Affairs (2016) Budget Justifications and Performance Information, Fiscal Year 2016, United States Department of the Interior, 
www.doi.gov/sites/doi.gov/files/migrated/budget/appropriations/2016/upload/FY2016_OIA_Gree nbook.pdf, accessed 20 August 2016.

O'Meara, T. (1987) 'Samoa: Customary individualism', in Crocombe, R. (ed.) Land Tenure in the Pacific (3rd ed.), Suva, University of the South Pacific, 74-113.

Oostindie, G. (2006) 'Dependence and autonomy in sub-national island jurisdictions: The case of the Kingdom of the Netherlands', The Round Table, 95(386), 609-626.

Orange, C. (2004) An Illustrated History of the Treaty of Waitangi, Wellington, Bridget Williams Books Ltd.

Osborne, J. B. (2014) 'Democratic transition in the development context: The case study of Tonga', unpublished Master of Development Studies thesis, Wellington, Victoria University of Wellington.

Osiander, A. (2001) 'Sovereignty, international relations, and the Westphalian myth', International Organization, 55(2), 251-287.

O'Sullivan, D. (2006) 'Needs, rights, nationhood, and the politics of indigeneity', MAI Review, Target Article, 1(1).

Otero, G. (2011) 'Neoliberal globalization, NAFTA, and migration: Mexico's loss of food and labor sovereignty', Journal of Poverty, 15(4), 384-402.

Ovendale, R. (1995) 'Macmillan and the wind of change in Africa, 1957-1960', The Historical Journal, 38(2), 455-477.

Overton, J. (1987) 'Fijian land: Pressing problems, possible tenure solutions', Singapore Journal of Tropical Geography, 8(2), 139-151.

Overton, J. (1989) Land and Differentiation in Rural Fiji, Pacific Research Monograph No. 19, Canberra, National Centre for Development Studies, Australian National University.

Overton, J. (1999) ' Vakavanua, vakamatanitu: Discourses of development in Fiji', Asia Pacific Viewpoint, 40(2), 173-186.

Overton, J. (2009) 'Reshaping development aid: Implications for political and economic relationships', Policy Quarterly, 5(3), 3-9.

Overton, J. (2011) 'Owning the Millennium Development Goals: Aid and development policy in the Pacific', in Lynch, B. and Hassall, G. (eds.) Resilience in the Pacific: Addressing Critical Issues, Wellington, New Zealand Institute of International Affairs, 93-107.

Overton, J. (2016) 'The context of overall aid in the Pacific: And its effectiveness', in Powles, M. (ed.) China and the Pacific: The View from Oceania, Wellington, Victoria University Press, 161-172.

Overton, J. and Murray, W. E. (2014) 'Sovereignty for sale? Coping with marginality in the South Pacific: The example of Niue', Hrvatski Geograkski Glasnik (Croatian Geographical Bulletin), 76(1), 5-25.

Overton, J. and Murray, W. E. (2016) 'Aid and the "circle of security"', in Grugel, J. and Hammett, D. (eds.) The Palgrave Handbook of International Development, Oxford, Palgrave Macmillan, 433-450.

Overton, J. , Murray, W. E. and McGregor, A. (2013) 'Geographies of aid: A critical research agenda', Geography Compass, 7(2), 116-127.

Overton, J. , Prinsen, G. , Murray, W. E. and Wrighton, N. (2012) 'Reversing the tide of aid: Investigating development policy sovereignty in the Pacific', Journal de la Société des Océanistes, 135, 229-242.

Oxfam (n.d.) 'Killer facts: Poverty in the Pacific', www.oxfam.org.nz/what-wedo/issues/millennium-development-goals/killer-facts-pacific-poverty, accessed 20 November 2015.

Patman, R. G. and Rudd, C. (2005) Sovereignty Under Siege? Globalization and New Zealand, Aldershot, Ashgate Publishing Ltd.

Peck, J. (2010) 'Zombie neoliberalism and the ambidextrous state', Theoretical Criminology, 14(1), 104-110.

Peck, J. , Theodore, N. and Brenner, N. (2010) 'Postneoliberalism and its malcontents', Antipode, 41, 94-116.

Perez, J. , Gistelinck, M. and Karbala, D. (2011) 'Sleeping lions: International investment treaties, state-investor disputes and access to food, land and water', Oxfam Policy and Practice: Agriculture, Food and Land, 11(1), 119-156.

Pérez, M. (2003) 'Australia's "Pacific solution": Regional imapct, global questions', The New Pacific Review, 2(1), 89-104. 
Pérez Silva, V. (2010) 'Los derechos del hombre, sociedades secretas y la conspiración de los pasquines', Credencial Historia, (241),

www.banrepcultural.org/blaavirtual/revistas/credencial/enero2010/derechos.htm, accessed 7 November 2015.

PIFS (2001) 'Forum economic ministers meeting', Record of Meeting Discussions 18-20 June 2001, Rarotonga, Cook Islands, PIFS.

PIFS (2004) Social Impact Assessment of Peace Restoration Initiatives in Solomon Islands, www.forumsec.org.fj/resources/uploads/attachments/documents/Social\%20Impact\%20of\%20Pe ace\%20Restoration\%20Initiatives\%20in\%20Solomon\%20Islands\%202004.pdf, accessed 12 September 2015, accessed 14 May 2015.

PIFS (2007) The Pacific Plan for Strengthening Regional Cooperation and Integration, Revised Version 2007, Suva, PIFS.

PIFS (2010) 'Pacific aid effectiveness principles',

www.forumsec.org.fj/resources/uploads/attachments/documents/Pacific_Aid_Effectiveness_Prin ciples_Final_2007.pdf, accessed 30 November 2010.

PIFS (2013) Pacific Plan Review 2013: Report to Pacific Leaders, Suva, PIFS.

PIFS (2015a) New Zealand's Development Cooperation in the Pacific: Report of the Forum Compact Peer Review 2015, Suva, PIFS.

PIFS (2015b) Pacific Regional MDGs Tracking Report 2015, Suva, PIFS,

www.forumsec.org/resources/uploads/attachments/documents/2015\%20Pacific\%20Regional\%2 0MDGs\%20Tracking\%20Report1.pdf, accessed 16 December 2016.

Pirnia, P. (2016) 'Cultivating ownership of development aid: The role of civil society in the Pacific', unpublished PhD thesis, Wellington, Victoria University of Wellington.

Pitty, R. and Smith, S. (2011) 'The indigenous challenge to Westphalian sovereignty', Australian Journal of Political Science, 46(1), 121-139.

Poirine, B. (1994) 'Rent, emigration and unemployment in small islands: The MIRAB model and the French overseas departments and territories', World Development, 22(12), 1997-2009.

Poirine, B. (1998) 'Should we hate or love MIRAB?', The Contemporary Pacific, 10(1), 65.

Pourmokhtari, N. (2013) 'A postcolonial critique of state sovereignty in IR: The contradictory legacy of a "West-centric" discipline', Third World Quarterly, 34(10), 1767-1793.

Powles, M. (ed.) (2016) China and the Pacific: The View from Oceania, Wellington, Victoria University Press.

Prasad, B. (2016) 'Soft loans and aid: China's economic influence in the Pacific', in Powles, M.

(ed.) China and the Pacific: The View from Oceania, Wellington, Victoria University Press,

176-179.

Prescott, S. M. (2008) 'Using talanoa in Pacific business research in New Zealand: Experiences with Tongan entrepreneurs', AlterNative: An International Journal of Indigenous Peoples, 4(1), 127-148.

Prime Minister's Office of Papua New Guinea (2014) Report 4 June 2014, Port Moresby, Office of the Prime Minister, www.officeofprimeminister.com/\#!june-2014/c1j7, accessed 12

September 2016, accessed 14 May 2016.

Prinsen, G. and Blaise, S. (2017) 'An emerging "islandian" sovereignty of non-self-governing islands', International Journal, 72(1), 56-78.

Prinsen, G. , Lafoy, Y. and Migozzi, J. (2017) 'Showcasing the sovereignty of non-selfgoverning islands: New Caledonia', Asia Pacific Viewpoint, 58(3), 331-346.

Radio New Zealand (2017) 'Taiwan and Tuvalu remain solid', www.radionz.co.nz/international/pacific-news/325786/taiwan-and-tuvalu-remain-solid, accessed 25 May 2017.

Rasmijn, A. (2013) 'Arubaanse regering wil geen homohuwelijk (Aruba Government does not want gay marriage)', Caribisch Netwerk, 13 June,

http://caribischnetwerk.ntr.nl/2013/06/13/arubaanse-regering-wil-geen-homohuwelijk/, accessed 20 April 2015.

Ratuva, S. (2011) 'The Chinese lake', The Listener, 2 May.

Ravuvu, A. (1983) Vaka i Taukei: The Fijian Way of Life, Suva, Institute of Pacific Studies, University of the South Pacific.

Ravuvu, A. (1988) Development or Dependence: The Pattern of Change in a Fijian Village, Suva, Institute of Pacific Studies, University of the South Pacific. 
Reus-Smit, C. (2011) 'Struggles for individual rights and the expansion of the international system', International Organization, 65(2), 207-242.

Richmond, O. P. (2011) 'De-romanticising the local, de-mystifying the international: Hybridity in Timor-Leste and the Solomon Islands', The Pacific Review, 24(1), 115-136.

Rist, G. (1997) The History of Development, London, Zed Books.

Robertson, R. T. (1988) 'Vanuatu: Fragile foreign policy initiatives', Development and Change, 19(4), 617-647.

Robertson, R. T. and Sutherland, W. (2001) Government by the Gun: The Unfinished Business of Fiji's 2000 Coup, Annandale, NSW, Pluto Press.

Robertson, R. T. and Tamanisau, A. (1988) Fiji: Shattered Coups, Sydney, Pluto Press.

Robie, D. (1989) Blood on Their Banner: Nationalist Struggles in the South Pacific, London, Zed Books.

Rocha Menocal, A. , Denney, L. and Geddes, M. (2011) Informing the Future of Japan's ODA, Part One: Locating Japan's ODA within a Crowded and Shifting Marketplace, London, Overseas Development Institute.

Ronnås, P. (1993) 'The Samoan farmer: A reluctant object of change?', Development and Change, 24(2), 339-362.

Routledge, D. (1985) Matanitū: The Struggle for Power in Early Fiji, Suva, Institute of Pacific Studies, University of the South Pacific.

Scheyvens, R. and Overton, J. (1995) "'Doing well out of our doing good": A geography of New Zealand aid', Pacific Viewpoint, 36(2), 192-207.

Scheyvens, R. (2002) Tourism for Development: Empowering Communities, Pearson Education.

Shubuya, E. (2004) 'The problems and potential of the Pacific Islands Forum', in Shibuya, E. and Rolfe, J. (eds.) Honolulu, Asia-Pacific Center for Security Studies, 102-115.

Scott, D. (1993) Would a Good Man Die? Niue Island, New Zealand and the Late Mr Larsen, Auckland, Hodder and Stoughton.

Selwyn, P. (1980) 'Smallness and islandness', World Development, 8(12), 945-951.

Sevele, F. (2011) 'Speech for the launch of the Vanuatu Energy Road Map', Manuscript, Port Vila.

Shaw, B. (1982) 'Smallness, islandness, remoteness and resources: An analytical framework', in Higgins, B. (ed.) Regional Development Dialogue Special Issue, Nagoya, UNCRD, 95-109. Simpson, G. (2008) 'The guises of sovereignty', in Jacobsen, T. , Sampford, C. and Thakur, R. (eds.) Re-Envisioning Sovereignty: The End of Westphalia?, Aldershot, Ashgate Publishing Ltd, 51-69.

Sisifa, S. P. (2015) 'The project management practices used in development projects: Reflections from Tonga', unpublished PhD thesis, Auckland, University of Auckland.

Smith, S. E. (2010) 'Uncharted waters: Has the Cook Islands become eligible for membership in the United Nations?', NZJPIL, 8, 169.

Spate, O. H. K. (1979) The Pacific since Magellan, Canberra, Australian National University. Stephen, S. (2001) 'Howard's "Pacific solution" is neo-colonialism', Green Left Weekly, www.greenleft.org.au/content/howards-pacific-solution-neo-colonialism, accessed 17 May 2017. Storey, D. (2004) The Fiji Garment Industry, Auckland, Oxfam New Zealand.

Storey, D. , Bulloch, H. and Overton, J. (2005) 'The poverty consensus: Some limitations of the "popular agenda", Progress in Development Studies, 5(1), 30-44.

Suaalii-Sauni, T. and Aiolupotea, S. M. (2014) 'Decolonising Pacific research, building Pacific research communities and developing Pacific research tools: The case of the talanoa and the faafaletui in Samoa', Asia Pacific Viewpoint, 55(3), 331-344.

Tabutaulaka, T. T. (2005) 'Australian foreign policy and the RAMSI intervention in the Solomon Islands', The Contemporary Pacific, 17(2), 283-308.

Talagi, F. Pihigia (2017) 'Paris in Niue: An analysis of the aid effectiveness agenda in Niue', unpublished Master of Development Studies thesis, Wellington, Victoria University of Wellington.

Taylor, M. (1987) 'Issues in Fiji's development: Economic rationality or aid with dignity', in Taylor, M. J. (ed.) Fiji: Future Imperfect?, Sydney, Allen and Unwin, 1-13.

Te Mato Vai (n.d.) 'Questions and answers',

www.tematovai.com/images/files/TMV_QA_September.pdf, accessed 28 May 2017. 
Thaman, K. H. (1993) 'A conversation about development', in Walsh, A. C. (ed.) Development That Works! Lessons from Asia-Pacific, Palmerston North, Amokura Publications, A4.1-A4.4. Thaman, K. H. (2003) 'Decolonizing Pacific studies: Indigenous perspectives, knowledge, and wisdom in higher education', The Contemporary Pacific, 15(1), 1-17.

Thoma, K. (2014) 'Electric vehicles in the Pacific Islands? An investigation of the possibilities of electro-mobility in Samoa', Master's thesis, Wellington, Victoria University of Wellington.

Thompson, R. C. (1994) 'Britain, Germany, Australia and New Zealand in Polynesia', in Howe, K. R. , (eds.) Tides of History: The Pacific Islands in the Twentieth Century, St, Leonards, NSW, Allen and Unwin, 71-92.

Thorne, A. and Raymond, R. (1989) Man on the Rim: The Peopling of the Pacific, Sydney, Angus and Robertson.

Ulu, A. J. (2013) 'Pule: Development policy sovereignty in Samoa', unpublished Master of Development Studies thesis, Wellington, Victoria University of Wellington.

UN (1945) Charter of the United Nations, www.un.org/en/documents/charter/index.shtml, accessed 18 May 2014.

UN (2013) General Assembly Adds French Polynesia to UN Decolonization List, 18 May, www.un.org/en/decolonization/site-news.shtml, accessed 20 May 2014.

UN (2015) Addis Ababa Action Agenda of the Third International Conference on Financing for Development (Addis Ababa Action Agenda), New York, United Nations.

UN (2017) Sustainable Development Knowledge Platform: Samoa,

https://sustainabledevelopment.un.org/hlpf/2016/samoa, accessed 3 June 2017.

UNA-UK (2017) Sustainable Development Goals: From Promise to Practice, London, United

Nations Association, UK, www.unglobalcompact.org/docs/publications/UNA-

UK\%20SDGS\%202017.pdf, accessed 3 June 2017.

UNFCC (2010) Report of the Conference of the Parties on Its Sixteenth Session, Held in Cancun from 29 November to 10 December 2010: Addendum: Part Two: Action Taken by the Conference of the Parties at Its Sixteenth Session,

https://unfccc.int/resource/docs/2010/cop16/eng/07a01.pdf, accessed 15 May 2017.

United Nations General Assembly (1960) Declaration on the Granting of Independence to Colonial Countries and Peoples, New York, United Nations.

United Nations General Assembly (2000) We the Peoples: The Role of the United Nations in the Twenty-First Century: Report of the Secretary-General, New York, United Nations,

http://unpan1.un.org/intradoc/groups/public/documents/un/unpan000923.pdf.

United Nations General Assembly (2007) Resolution 61/295: United Nations Declaration on the Rights of Indigenous Peoples, www.un.org/esa/socdev/unpfii/documents/DRIPS_en.pdf, accessed 13 September 2009.

US-GAO (2013) Compacts of Free Association: Micronesia and the Marshall Islands Continue to Face Challenges Measuring Progress and Ensuring Accountability, 20 September, www.gao.gov/assets/660/658031.pdf, accessed 20 August 2015.

Vaioleti, T. M. (2006) ' Talanoa research methodology: A developing position on Pacific research', Waikato Journal of Education, 12, 21-34.

Van Beverhoudt, A. E. (2003) America's Tropical Isles,

www.sandcastlevi.com/travel/isles/intro.html, accessed 8 November 2015.

Voi, M. (2000) 'Vaka moana: The ocean roads', in Hooper, A. (ed.) Culture and Sustainable Development in the Pacific, Canberra, Asia Pacific Press and Australian National University, 207-220.

Voigt-Graf, C. (2008) 'Migration and transnational families in Fiji: Comparing two ethnic groups', International Migration, 46(4), 15-40.

Wallace, T. , Bornstein, L. and Chapman, J. (2007) The Aid Chain: Coercion and Commitment in Development NGOs, Rugby, Intermediate Technology Publications and Practical Action Publications.

Ward, R. G. (1965) Land Use and Population in Fiji: A Geographical Study, London, H.M.S.O.

Ward, R. G. (1967) 'The consequences of smallness in Polynesia', in Benedict, B. (ed.)

Problems of Smaller Territories, London, Althone Press, 81-96.

Ward, R. G. (1985) 'Land, land use and land availability', in Brookfield, H. C. , Ellis, F. and Ward, R. G. (eds.) Land, Cane and Coconuts, Canberra, Department of Human Geography, Research School of Pacific Studies, Australian National University, 15-64. 
Ward, R. G. (1987) 'Native Fijian villages: A questionable future?', in. Taylor, M. J. (ed.) Fiji: Future Imperfect?, Sydney, Allen and Unwin, 33-45.

Ward, R. G. and Kingdon, E. (eds.) (1995) Land, Custom and Practice in the South Pacific, Cambridge, Cambridge University Press.

Warner, N. (2003) "100 Days of RAMSI": Message to the People of Solomon Islands, www.ramsi.org/Media/docs/031031-Special-Coordinator-Nick-Warner-100-days-of-RAMSI9cd1906a-907f-40da-aaba-0b96082a2ea0-0.pdf, accessed 16 May 2016.

Warrick, O. (2009) 'Ethics and methods in research for community based adaptation:

Reflections from rural Vanuatu', in Reid, H. (ed.) Community-Based Adaptation to Climate Change, London, International Institute for Environment and Development, 76-87.

Watters, R. (1987) 'MIRAB societies and bureaucratic elites', in Hooper, A. , Britton, S. , Crocombe, R. , Huntsman, J. and MacPherson, C. (eds.) Class and Culture in the South Pacific, Auckland and Suva, Centre for Pacific Studies, University of Auckland, New Zealand and Institute of Pacific Studies, University of the South Pacific.

Wesley-Smith, T. (2007) 'Self-determination in Oceania', Race and Class, 48(3), 29-46.

Wesley-Smith, T. (2016) 'Reordering Oceania: China's rise, geopolitics, and security in the Pacific Islands', in Powles, M. (ed.) China and the Pacific: The View from Oceania, Wellington, Victoria University Press, 98-110.

Wood, T. (2015) 'The ups and downs of New Zealand aid: Budget 2015', Blog, www.cid.org.nz/news-old/the-ups-and-downs-of-new-zealand-aid-budget-2015/, accessed 20 May 2017.

World Bank . (2000). Partners in Transforming Development: New Approaches to Developing Country-Owned Poverty Reduction Strategies. Washington DC: World Bank. Retrieved from http://www.imf.org/external/np/prsp/pdf/prspbroc.pdf, accessed 7 January 2017.

Wrighton, N. (2010a) 'So what's the problem? International development arrivals in Tuvalu', Just Change, 18, 9.

Wrighton, N. (2010b) 'Participation, power and practice in development: A case study of theoretical doctrines and international agency practice in Tuvalu', unpublished Master of Development Studies thesis, Wellington, Victoria University of Wellington.

Wrighton, N. and Overton, J. (2012) 'Coping with participation in small island states: The case of Tuvalu', Development in Practice, 22(2), 244-255.

Young, I. M. (2004) 'Two concepts of self-determination', in May, S. , Modood, T. and Squires, J. (eds.) Ethnicity, Nationalism, and Minority Rights, Cambridge, Cambridge University Press, 176-196.

Zwart, P. (2016) 'The tripartite China/New Zealand/Cook Islands project: A New Zealand perspective', in Powles, M. (ed.) China and the Pacific: The View from Oceania, Wellington, Victoria University Press, 208-214. 